\title{
Suriye Coğrafyasında 1919 - 1921 Döneminde Siyasal Ve Sosyal Olaylar Ve Türkiye - Fransa İlişkileri
}

\author{
Mustafa Yahya METINTAŞ ${ }^{l}$
}

\section{Özet}

Türkiye'nin bölgesel ve küresel olarak etkin politikalar geliştirebilmesi bölge tarihinin iyi incelenmesine, irdelenmesine ve yorumlanmasını bağlıdır. Bu noktadan hareketle araştırmamızda, Fransa'nın Birinci Dünya Savaşı boyunca Orta Doğu coğrafyasına yönelik politik tavrı, uygulamaları ile bunlara karşı geliştirilen Türk politikaları incelenmiş, Suriye ilişkileri ekseninde, tüm aktörlerin politikaları dikkate alınarak bölgede yaşanan siyasi ve askeri gelişmelerin sonuçlarının tartışılması ve bugüne olan tesirlerinin anlaşılabilmesi amaçlanmıştır.

Araştırma boyunca, Arap liderlerinin İngiliz ve Fransızların politik yönlendirmelerinden nasıl etkilendikleri, Mustafa Kemal Atatürk ve Milli Mücadele'nin diğer liderlerinin Araplarla işbirliği konusundaki görüş ve düşünceleri, Türk milis güçleri ile Suriye'deki bağımsızlıkçı Arapların verdikleri ortak mücadele, Ankara Hükümeti-Fransa ilişkileri ve Ankara İtilafnamesi’nin imzalanmasına kadar gerçekleşen olaylar, arşiv belgeleri ve konuyla ilgili makale ve kitaplar, basılı olan ve olmayan akademik tezler, gazeteler vs. yararlanılarak değerlendirilmiştir. Araştırma, amacı gereği, Türkiye'nin Suriye ilişkilerini anlamlandırabilmek için Suriye coğrafyasında, sosyolojik ve tarihi dengenin ilk bozulduğu andan başlamak üzere temellendirilmiştir.

Anahtar Kelimeler: Suriye, Türk Kurtuluş Savaşı, Ankara Antlaşması

\section{The Political And Social Events In The Period Of 1919 - 1921 At Syria Geography And In The Same Period Turk - French Relations}

\begin{abstract}
The developing effective regional and global policies for Turkey depends on the well-studied region's history, analyse and emphasised it. From this point of view, in our study, the political attitude and practices of France towards the Middle East post World War I and the Turkish policies had been developed against them were examined. In the context of Syrian relations, it is aimed to discuss the results of the political and military developments in the region taking into account the policies of all the actors and to understand the effects on the present.

Throughout the research, how the Arab leaders were influenced by the political orientations of the British and French. Mustafa Kemal Atatürk and other leaders of the National Struggle shared their opinions and arguments on the cooperation with Arabs. The common struggle of independence groups in both Turkish national struggle and Arabs in Syria. Considered through the process, archive documents, printed documentary sources and other literature. Research should aim, to make sense of the Turkey's Syrian relations, since it was starting from the first sight of loss sociological and historical balance in Syria.
\end{abstract}

Keywords: Syria, Turkish War of Independence, Ankara Agreement

${ }^{1}$ Dr. Öğr. Üyesi, Osmangazi Üniversitesi, Fen Edebiyat Fakültesi, Tarih Bilim Dalı, Türkiye Cumhuriyeti Tarihi Anabilim Dalı, mmetintas@ hotmail.com 


\section{Giriş}

Son yıllarda Suriye coğrafyasında yaşananlar; dünyanın büyük güçlerinin o topraklardaki askeri varlıkları, müdahaleleri, etnik gruplara yaptıkları silah, para yardımları, onları eğitip, organize ederek güçlendirmeleri, yaşanan çatışmalara süreklilik kazandırmaktadır. Suriye merkezi yönetimi tamamen Rusya'nın kontrolüne teslim olmuş durumdadır. İktidarını sürdürebilmek ve ülkede kontrolü yeniden sağlayabilmek için kendi halkına yönelik katliamlardan kaçınmamaktadır. Bu gelişmeler, bugünlerde hem bölgemizin hem de dünyanın önde gelen sorunlarından birini oluşturmaktadır. Tarihin bu döneminde yaşananları anlayabilmek için o coğrafyada yakın geçmişte yaşananları iyi incelemek ve değerlendirmek gerekmektedir.

Tarih boyunca söz konusu bölge, sömürgeci nitelikli büyük devletlerin ilgi alanına girmiştir. Fransa, bölgenin tarihi seyrini yönlendiren devletlerden birisi olup, Haçlı Seferlerinden bu yana Ortadoğu'da sözünü geçirebilmek için Suriye üzerine odaklanmıştır (Fromkin 1993: 84). Fransa, Kanuni Sultan Süleyman döneminden itibaren Akdeniz'de koloniler kurmak için Türk-Fransız ananevi dostluk siyasetini bir vasıta olarak kullanmış, kapitülasyonlar sayesinde iktisadi ilişkiler kurmak için Suriye'yi ana giriş ve çalışma bölgesi seçerek, bölgedeki iktisadi düzen ile Fransa arasında iktisadi bir bağ kurmaya çalışmıştır (Akyüz 1988: 180; Gürel 1988: 110). Osmanlı Devleti’nin zayıflamaya başlaması ile birlikte bölgede Fransız politikası değişmiştir. Fransa, özellikle Osmanlı Devleti bünyesinde bulunan Hristiyanların korunması sorununu ileri sürerek Devletin iç ve dış düşmanlarına yardım etmeye, hatta gerekli gördüğünde yeni düşmanlar yaratarak Osmanlı Devletine karşı kullanmaya başlamıştır.

Osmanlı Devleti'nin zayıfladığı yıllarda, Fransa'nın Osmanlı Devleti sınırları dâhiline sızabilmek için bugün Suriye diye bilinen coğrafyanın özellikle Hıristiyanların yaşadığı Doğu Akdeniz'in kıyı bölgelerini kullanmıştır. Fransa, 19.Yüzyılın ikinci yarısından itibaren, bölgenin merkezi sayılabilecek Beyrut'ta yaşayan Hristiyan Araplar aracılı̆̆ ile bölgeye girmiştir. Beyrut'ta Fransız Konsoloslarının koordinasyonu ile özellikle 19. Yüzyılın ikinci yarısından itibaren Katolik dini merkezleri, misyoner okulları ve misyoner hastaneleri kurulmuştur. Bunlar Lübnan'ın ardından Suriye'nin tamamına yayılır, kapitülasyonlar sayesinde de Osmanlı yönetiminden bağımsız şekilde faaliyet gösterirler (Birsel 2012: 39). Öyle ki, Birinci Dünya Savaşı başladığında Fransız kültürü ve nüfuzu Suriye topraklarına oldukça yayılmış ve yerel halk ve yerel yöneticilerce kabullenilmiş durumdadır.

20.Yüzyılın başından itibaren "bağımsızlık ideali" çerçevesinde örgütlenmeye başlayan Lübnanlı Hristiyan ve Müslüman Araplardan oluşan Suriye Arap bağımsızlık hareketi Osmanlı hâkimiyetine karşı Fransızlardan açık çağrılar ile yardım istemiştir. Konuyla ilgili Cemal Paşa'nın verdiği bilgiler dikkat çekicidir. Cemal Paşa, Birinci Dünya Savaşı başlangıcında ayrılıkçı Arap yerel liderlerin yargılandığı Divanı Harp Mahkemesi ile ilgili kitabında, Fransa'nın Kahire'deki siyasi temsilcisinin ağzından şu sözleri duyduğunu ifade etmektedir (Okur 2009: 139): 
"Şayet Suriye bir gün ecnebi himayesi altına girecek ise Suriyeli Hiristiyanlar hemen müttefiken bu himayenin Fransa himayesi olmasını arzu edeceklerdir. Müslümanlar arasinda ise gayet müteneffiz bir kısım Ingiltere himayesini tercih, diğer bir kısmı da Fransa himayesini kabul edip mütebâkisi kendilerinin giyabinda takarrür edecek herhangi bir himayeyi lakaydâne kabul ederler.

Osmanlı Devleti, Birinci Dünya Savaşı sonlarına doğru, bir yandan isyancı Araplar bir yandan da onları kullanan İtilaf Devleri ile yapılan çetin savaşların kaybedilmesi sonucu, ciddi müdafaa gayretlerine rağmen Arap coğrafyasındaki hâkimiyetini kaybetti. Fransa ise Birinci Dünya Savaş1 sırasında ve sonrasında yapılan paylaşım anlaşmaları ile Ortadoğu'yu, dolaylı da olsa yönetme imkânı buldu. Üstelik Fransa, Avrupa'da savaşın yükünü omuzlayan ülke olarak Ortadoğu'daki mandalarını bölgedeki askeri harekâtlarla değil (Jackson 2013: 121), Batı Cephesi’nde sürdürülen diplomatik müzakerelerle elde etmiştir². Fransızların Suriye Filistin cephesindeki askeri varlıkları, bu cephede savaşan diğer tarafların (İngiltere, Osmanlı Devleti, Arap isyancılar) asker sayıları dikkate alındığında kayda değer bir miktar ifade etmiyordu (Fildiş 2013: 57).

Birinci Dünya Savaşı sonrası Anadolu'da kurulan Türkiye Büyük Millet Meclisi (TBMM) Hükümeti, coğrafi olarak önemli bir kısmı yitirilmek üzere olan, ekonomik açıdan tamamen çökmüş, büyük etnik çatışmalar ve katliamların gerçekleştiği Anadolu'da Meclisin açılışı öncesi belirlenen "Misakı Milli" ilkeleri ve stratejisi çerçevesinde bir "Milli Mücadele" hareketi oluşturarak kontrolü eline almaya ve gelişmeleri yönlendirmeye çalışmıştır.

Özellikle 1921'den itibaren uluslararası siyasi alanda TBMM Hükümeti İstanbul Hükümetinden giderek daha fazla muhatap kabul edilmiştir. TBMM, Milli Mücadele sırasında, Anadolu ve Arap coğrafyasında "emperyalizme karşı halklar ve milletler arasındaki dayanışma, yardımlaşma ve işbirliği ile gerçekleşecek milli kurtuluş mücadelelerini" politik bir tavır olarak benimsemiştir. Bu tavır ve sonrası gelişmeler, Anadolu'da ve kısmen çevre coğrafyada sağlanan başarı tarihin, sosyolojinin ve sosyal psikolojinin o dönemin siyasi liderlerince iyi okunduğunu, bilimsel analizlere dayanan stratejiler geliştirildiğini göstermektedir (Bıyıklı 2008: 318 - 319).

Bugün Suriye coğrafyasında yaşananları yerel ve bölgesel olarak anlamlandırabilmek, olacakları başarılı bir şekilde kestirebilmek ve doğru politikalar geliştirebilmek için Fransa'nın Suriye üzerindeki faaliyetlerini, bu bağlamda Suriye üzerinden Türk - Fransız ilişkilerini iyi incelemek, değerlendirmek ve tartışmak gerekmektedir. Bu noktadan hareketle araştırmamızda, Fransa'nın Birinci Dünya Savaşı boyunca Orta Doğu coğrafyasına yönelik politik tavrı, uygulamaları ile bunlara karş1 geliştirilen Türk politikaları incelenmiş, iki taraflı yaşanan Suriye ilişkileri ekseninde -diğer aktörlerin de politikaları dikkate alınarak- bölgede yaşanan siyasi ve askeri gelişmelerin sonuçlarının tartışılması ve bugüne olan tesirlerinin anlaşılabilmesi amaçlanmıştır.

\footnotetext{
${ }^{2}$ Fransa, Avrupa Kıtasında özellikle Kuzey ve Orta Fransa ile Belçika'da Almanya’ya karşı yürütülen savaşın yükünü omuzlayan devlet olmuştur. İngiliz ordusu bu bölgelerde Fransa'ya destek amacıyla bulunmuştur.
} 
Araştırma boyunca Arap liderlerinin İngiliz ve Fransızların politik yönlendirmelerinden nasıl etkilendikleri, beklenmedik gelişmeler karşısındaki tutum ve davranışları, Emir Faysal'ın Suriye Kralı olduktan sonraki faaliyetleri, Fransa'nın bölge politikaları, Mustafa Kemal Paşa ve Milli Mücadele'nin diğer liderlerinin Araplarla işbirliği konusundaki görüş ve düşünceleri, Kuvayı Milliye hareketi mensupları ile Suriye'deki bağımsızlıkçı Arapların, bağımsızlık ve özgürlükleri için verdikleri ortak mücadele, Ankara Hükümeti-Fransa ilişkileri, Ankara İtilafnamesi'ne uzanan süreç, arşiv belgeleri, belgesel resmi kaynaklar, konuyla ilgili kitap ve makaleler incelenerek değerlendirilmiştir.

$\mathrm{Bu}$ değerlendirme süreci, gerçekleşen ve yaşananların etki alanlarının genişliği, yoğunluğu, dağınıklığı, aktörlerin çeşitliliği, etnisite ve inanç farklılıkları, coğrafi ve kültürel farklılıklar, Batılı güçlerin karmaşık müdahaleleri gibi siyasi, askeri, sosyal, psikolojik ve antropolojik nedenlerle sıralı olarak yürütülmüştür.

\section{Suriye'de Arap İsyancıların Başarısı Sonrası Siyasi Gelişmeler}

Birinci Dünya Savaşı sırasında Osmanlı Devleti’nin karşılaştığı Arap isyanı, seyri ve arka planı itibariyle tam bir "sömürgeci-yerli işbirlikçi”" eylemidir. İsyancılar, isyan boyunca İngiliz ve kısmen Fransız askeri güçleri ile ortak hareket etmişlerdir. Osmanlı ordusunun, Şam’ı boşaltmasının ardından, İngilizlerin davetiyle 3 Ekim 1918 tarihinde şehre giren Emir Faysal (Güztoklusu 2010: 115), babası Şerif Hüseyin gibi büyük Arap krallığının kurulup yaşatılmasında İngilizlerin desteğine çok önem veriyor ve İngiliz desteği ve koruması olmadan bunun başarılamayacağını düşünüyordu (Uçar 1989: $61)$.

Suriye olarak kabul edilen topraklarda yerel güçlere karşı hâkimiyetini kurmasına yetecek düzeyde milis birliklere sahip olan Emir Faysal, Fransız birliklerinin bulunduğu sahil şeridi hariç, bütün Suriye'yi kısa zamanda kontrolü altına almış, iki yıla yakın bir süre Suriye'de etkili olduğu bölgeyi bağımsız bir devlet gibi yönetmiştir (Okur 2009: 140). Bu süreçte Emir Faysal, Suriye'nin bağımsızlığını uluslararası düzeyde kabul ettirmeye çalışmış, ayrıca kendi otoritesini devlet düzeyinde tesis için yoğun bir çalışma içerisine girmiştir. Çünkü Emir Faysal'ın karşısında Suriye'nin hızla çözüm bekleyen iç sorunlarının yanında bölge üzerinde hak iddia eden Fransızların manda talepleri vardır. Üstelik bu talep bir resmi antlaşma ile İngilizler tarafından da onaylanmıştır (Sykes-Picot). Fransızlar Emir Faysal'ı ve Arap milliyetçilerini dinlemeyeceklerdir zira Suriye’ye yerleşmek hususunda kararlıdırlar.

Arapların bağımsızlık kararlılıkları, Suriye topraklarının bağımsız bir Arap krallığına dönüşmesinin Fransa için kabul edilir bir durum olmaması ikilemi karşısında İngiltere aracı role döner. Emir Faysal, İngilizlerin isteği üzerine Şerif Hüseyin'i ve Arapları temsilen 18 Ocak 1919'da çalışmalarına başlayan Paris Barış Konferansı'na katılır. Emir Faysal, konferans sırasında 6 Şubat 1919’da konferans1 yöneten “Onlar Konseyi”ne Arap isteklerini resmi nitelikle sunar. Faysal, bölgede Arapça konuşan halkların tam bağımsızlığını ve bir devlet bütünlüğünde birleştirilmesini ister, bu 
talebine gerekçe olarak savaşta Arapların İtilaf Devletleri safında yer alarak, verilen görevleri tam olarak yaptıklarını, onların da Mondros Mütarekesi sonrası bir bildiri yayınlayarak Arap bağımsızlığını destekleyeceklerini ilan ettiklerini belirtir. Emir Faysal, Birinci Dünya Savaşı sırasındaki gelişmelere paralel olarak hazırlanan ve Arap coğrafyasının paylaşımı esaslarının belirlendiği Sykes-Picot Anlaşmasına karşı çıkar; isyanı başlattıkları sırada böyle bir anlaşmadan haberleri olmadığını, anlaşmanın gerçekçi olmadığını ve buna göre çizilen sınırların kalıcı olmasını ve barış getirmesini kimsenin beklememesi gerektiğini 1srarla belirtir (Tanenbaum 1978: 7-11). Ancak Paris Barış Konferansında Faysal'ın çabaları ve 1srarlı bağımsılılı talepleri herhangi bir karşılık bulmamıştır (Demir 2011: 695).

Emir Faysal, Paris’te İtilaf Devletlerinin asıl niyetlerinin Suriye ve diğer Arap topraklarını parçalayarak, sömürgeleştirmek olduğunu anlamıştır, yol arkadaşlarına ulaştığı kanaati şöyle anlatır: “Müslüman dünyasının önüne çıkamayacağım. Kendilerinden Halifeye karşı savaşmalarını, fedakârlık yapmaların istedim. Oysa şimdi görüyorum ki, amaçlarına hizmet ettiğimiz Avrupa devletleri Arap ülkelerini bölüyorlar" (Kocabaş 1993: 103).

Paris Konferansı'nda, beklediği desteği bulamayan, Emir Faysal, Nisan 1919 sonunda Şam'a döner. Kendisini karşılayan Suriyeli milliyetçi liderlere görüşmelerin sonuçlarıyla ilgili olarak özetle şu açıklamay1 yapar (Umar, 2004: 404): "Şu ana kadar Avrupa devletleriyle bir ittifak ve anlaşması olmamıştır. Barış Konferansında sadece Suriye’nin değil tüm Arapların bağımsızlı̆̆ını istedim... Muhakkak ki bă̆ımsızlık alınır, verilmez. Onu elimizle, kuvvetimizle alacă̆ız..."

Emir Faysal, Suriye'ye döndükten sonra, Arap bağımsızlığg yönelik çözümü ilk aşamada askeri ve siyasi mücadelede arar (Tüzün 1989: 32). Bundan sonrası Suriye'de belirsizlik ve karışıklığın daha da artacağı bir dönemdir (Davulcu 2007: 119).

\subsection{Suriye İtilafnamesi}

İngiltere, kendi sömürgeci beklentileri gereği, Fransa'nın ideallerini kısmen kontrol etmeye çalışır, Suriye'de Emir Faysal yönetiminde bir Arap krallığının kurulması, ama bu krallığın Fransa ile de uyumlu olmasında, biraz ikili, biraz bütüncül bir politikada ısrarcı davranır. Nitekim İngiltere'nin Fransa'ya göre kısmen farklı gibi görünen politikalarına rağmen, Temmuz 1919'da iki başbakan, Clemenceau ile Lloyd George arasındaki görüşmeler sonucunda Adana, Maraş, Antep, Urfa, Kilikya ve Suriye'de İngiliz birliklerinin yerine Fransız birliklerinin geçmesi konusunda mutabık kalınır. Anlaşmaya göre Emir Faysal, askeri ve siyasi olarak sadece Şam ve Halep şehirlerinde hâkimiyet sahibi olabilecektir, üstelik bu da Fransız himayesi altında olacaktır (Zamir 1991: 412).

Emir Faysal, İngiltere ve Fransa'nın tutumları karşısında Arap milliyetçilerini yatıştırmaya ve bir arada tutmaya gayret ederken, Fransız tasarılarının uygulanmasını olabildiğince geciktireceğini düşündüğü tedbirleri hayata geçirmeye çalışmıştır. Sömürgeciliğe karşı Amerika Birleşik Devleti'nin ilgisini bölgeye çekmeye çalışmış, Suriyeli Arapları bir arada tutabilmek için bir Suriye Genel 
Kongresinin toplanması çalışmalarına öncülük etmiştir. Bu konuda Faysal'ın en büyük yardımcısı bağımsızlık yanlısı El Fetat Cemiyeti ${ }^{3}$ olmuştur (Bilgenoğlu 2006: 65). Emir Faysal'ın düşüncesine göre bir genel kongrede tüm Suriye'den temsilciler bir araya gelebilir, burada "Bağımsızlık", "Arap Birliği”" konularında atılacak adımlar belirlenebilecektir.

Arap milliyetçiler ve Emir Faysal, Fransa'nın Suriye ile ilgili tasarılarına karşı ortak bir politik tavır oluşturabilmek üzere 2 Temmuz 1919'da 120 üyenin katılımıyla "Suriye Genel Kongresi" çalışmalarını başlatmışlardır (Karasapan 1942: 235). Suriye Kongresinin esas görevi Suriye'de yaşayan insanları Suriye'nin birliği ve bağımsızlığı hedefi ile bu hedefe gerekirse silah ile ulaşılması fikri etrafinda toplamaktı.

Kongre çalışmalarını sürdürürken, İngiltere ve Fransa aralarında varılan mutabakatı Emir Faysal'a sunmak, kabul ettirmek ve belki de devam eden Kongre'nin yönünün değişmesini sağlayıp, aralarındaki anlaşmayı tanıtıp onaylattırmak üzere Emir Faysal'a çağrı yaptılar. Çağrı üzerine Faysal, Ağustos 1919'da görüşmelerde bulunmak üzere Avrupa'ya gider (Haas 1952: 311 - 356). Faysal'ın bu ziyaretten beklentisi, Suriye'nin parçalanmasını engellemek ve bağımsızlığı fikrini Avrupalılara bir kez daha kabul ettirmeye çalışmaktır.

Fransız Başbakan Clemenceau, Emir Faysal'ın tam bağımsızlık tezini yine kabul etmez, İngiltere ile vardığı uzlaşmaya dayanarak Arapları "Fransız Mandası Yönetimi Tasarısının” bazı hükümleri hafifletilmiş bir versiyonunu kabul etmeye zorlar (Haas 1952: 362). Kısaca Fransa, Fransız yöneticilerin Suriye'nin yönetiminde söz sahibi olmasından, demiryollarını ve ülke kaynaklarını Fransızların yönetmesinden ve ülkeyi bir sömürge haline getiren diğer ilkelerden taviz vermez. Emir Faysal, taslağı Suriye'de yol arkadaşları ve halka danışacağını söyleyerek imzalamaz ve Suriye'ye döner. Bundan sonra Emir Faysal'ın ikiyüzlü, kendi siyasi ve idari otoritesini koruyup, Fransız-İngiliz anlaşmasını da kabullenen bir diplomasi ve siyaset uygulamaya başladığı gözlenir (Kasalak 2006: 72). Bir diğer ifadeyle Emir Faysal'ın sonraki siyasetinde, Fransızların kendisine sunduğu taslağı açıkça reddetmeyerek hem Suriye'de Fransız mandası kurulmasını hem de bu planın Arap milliyetçilerine kabul ettirilmesi görevini kabul ettiğine dair bir ihtimal kuvvetle muhtemeldir. Nitekim Faysal, Şam'daki milliyetçi Arap cemiyetlerinin liderlerine Fransız taslağının reddinin savaş demek olacağını anlatmaya çalışmıştır. Arap milliyetçiler ise, gerekirse hem İngiltere ve hem de Fransa ile savaşa hazırız mesajını Faysal'a iletmişlerdir. Artık Arap isyancılar bölünmüştür; bir yanda tam bağımsızlıkçı Arap milliyetçiler, bir tarafta Fransız mandasını kabullenen Emir Faysal ve taraftarları vardır. Böylece, yakın coğrafyada, Anadolu'da bağımsızlık ve özgürlük için mücadele veren kadroların Suriye'deki yolları açılmıştır. Heyeti Temsiliye ve sonrası TBMM'nin bölgeye nüfuzu, daha sonraki bölümde ayrıntıları verileceği üzere bağımsızlık yanlısı Arap milliyetçiler üzerinden gerçekleşecektir. Nitekim Suriye

\footnotetext{
${ }^{3}$ El-Fetat Cemiyeti veya Genç Araplar Cemiyeti 1911'de Paris'te, İzzet Derveze tarafindan kurulan Arap milliyetçisi bir cemiyettir. Cemiyet, Osmanlı'da Arap milliyetçiliği güden gizli bir oluşumdur. Amacı, Osmanlı hâkimiyeti altındaki tüm Arapların birleşmesi ve bağımsızlığını sağlamasıdır.
} 
genelinde yer yer protesto gösterileri çıkmış, hatta bu dönemde milliyetçi Araplar tarafından Emir Faysal'a yönelik bir suikast planlanmış, ancak uygulamada başarılı olmamıştır (Hâkimiyeti Milliye 6 11 Şubat 1921; Y1lmaz 2014: 295).

Temmuz 1919'da sürdürülen, Ağustos 1919'da devam eden görüşmelerle geliştirilen, Orta Doğu coğrafyasının paylaşıldığı, Emir Faysal'a da dayatılan anlaşma, 15 Eylül 1919'da İngiltere ve Fransa arasında tam mutabakat olarak imzalanır. Bu anlaşma tarihte "Suriye İtilafnamesi" olarak anılmaktadır (Akbıyık 1990: 52). Suriye İtilafnamesi ile İngiltere, yukarıda belirtildiği gibi, Musul ve Filistin'i almış karşılığında da Suriye, İskenderun ve Kilikya'yı Fransa'ya vermiştir (Fromkin 1994: 157). Büyük bağımsız Arap krallığı vaatleri ile aldatılan Araplar ise bu gelişmeleri yalnızca izlemişlerdir. Anlaşma hükümleri, coğrafi paylaşım nedeniyle Anadolu'yu da doğrudan etkilemektedir. Suriye İtilafnamesine, bekleneceği gibi Arap bağımsızlık taraftarları büyük tepki gösterirler. Şam'da büyük bir infial doğar. Emir Faysal'a en yakın desteği veren gruplar dahi, Suriye'nin herhangi bir parçasının Fransızlara verilmesine karşı tavır alırlar; savaş sırasında kendilerine verilen isyan görevini başarıyla gerçekleştirdiklerini, bu yüzden kendilerine resmen verilen Arap bağımsızlığı vaadinin eksiksiz yerine getirilmesini tekraren dile getirirler.

Yoğun Arap muhalefeti üzerine Fransa, itilafnameyi kabul ettirebilmek amacıyla, görüşmelerde bulunmak üzere Emir Faysal'ı tekrar Fransa'ya davet eder. 1919 yılı sonlarında Fransa'ya giden Faysal, davetin verdiği umudun aksine, diplomatik ve idari olarak yine soğuk bir tavır ile karşılanır. İngiltere'ye geçen Faysal, İngiltere'de General Edmund Allenby ve başka temsilcilerle görüşür. Faysal'ın Suriye'de alacağı krallık kararının, pratikte yönetim yetisi pek olmasa da siyaseten kabul edileceği teminatı verilir (Zamir 1991: 404).

İngiltere ve Fransa, Suriye - Filistin Cephesi ile Irak Cephesinde başarılı olmalarına yardımcı olan Arapların topraklarını, Arap bağımsızlığı için verdikleri söz ve fiili desteğe rağmen hızla hâkimiyetleri altına almaya başlayınca (Sonyel 1987: 183-184), Anadolu'da başlayan Milli Mücadele hareketi toprakları hızla sömürgeleştirilen Arap halkları için sarılacak tek güvenilir umut kaynăğ olarak belirir, Anadolu Hükümeti de bu yönde gayret göstermeye başlar (Akşin 1991: 191).

\section{Türkiye Büyük Millet Meclisi Hükümeti'nin Suriye'deki Faaliyetleri ve Suriye}

\section{Merkezli Fransa İlişkileri}

\subsection{Milli Mücadelede Türkiye Büyük Millet Meclisi’nin Suriye Politikası}

Milli Mücadele'nin lideri Mustafa Kemal Paşa, Birinci Dünya Savaşı sonunda Anadolu'da ve Müslümanların yaşadığı coğrafyalarda başlayan işgal, ilhak ve sömürgeleştirme hareketlerini, Anadolu'da, Asya'da ve Arap coğrafyasında tüm doğu milletlerine ve İslam âlemine karşı başlatılmış topyekûn bir saldırı olarak değerlendirmekte, bu konuda İslam dünyasına beyannameler, bildiriler göndererek, onları İngiliz, Fransız ve İtalyan emperyalizmine karşı yerel milli mücadelelere çağırmaktadır (Bıyıklı 2008: 325). Mustafa Kemal Paşa, 1919 Temmuzunda sömürgeci, devletlerin 
faaliyetlerine karşı bilinçlenen mazlum halkların mücadeleleri hakkındaki görüşlerini şöyle ifade etmiştir (Soysal 2000: 119):

“Afganistan, Mısır, Irak ve Suriye Müslümanları İngiltere'nin ve Fransa'nın topraklarını sömürgeleştirme çabalarına karşı cesaretle mücadele halindedirler."

Milli Mücadele'nin liderlerine göre Anadolu'da nasıl bir sömürgeci işgal ve zulüm varsa, neredeyse İslam dünyasının tamamında da benzer bir sömürgeliştirme çabası vardır. Anadolu ile bütün İslam topluluklarının, özellikle de yakın coğrafyanın kaderi arada kurulacak sıkı işbirliğine bağlıdır. Bu noktada, Anadolu'daki mücadelenin başarıya ulaşması için dünya'nın farklı bölgelerinde yaşayan İslam toplumlarının ve Arap coğrafyasının Anadolu'da verilmekte olan savaş konusunda bilgilendirilmelerine, ilgi ve desteklerinin sağlanmasına hayati bir önem verilmiştir. Mustafa Kemal Paşa, bütün İslam ülkelerine ve İslam merkezlerine gönderilen mektuplarla işgal, ilhak ve sömürgeleştirme işlerinin Anadolu'nun da başına getirilmeye çalışıldığını, buna karşı Anadolu'da nasıl bir kutsal gaye ile mücadele edildiğini, Anadolu'da yaşayan Müslümanların emperyalist saldırının zulmü altında nasıl sıkıntı çektiklerini, İslam topraklarının bağımsızlığının ne kadar önemli olduğunu dünyadaki Müslüman halklara ve topluluklara anlatmaya çalışmıştır (ATASE, Kls. 584, Dos. 8 - 141, Fih. 5-1). Çünkü İslam toplumlarının desteği, İslam'ın korunması adına Anadolu'da mücadele eden kadroların moral motivasyonlarının arttıılması açısından gerekliydi. İslam coğrafyasında doğabilecek siyasi / manevi liderlik de İngiliz ve Fransız politikalarını etkileyebilirdi.

İngiltere ve Fransa'nın Ortadoğu'da mandacılık sistemi adı altında hakimiyetleri altına almaya çalıştıkları coğrafya, Anadolu'da başlayan Milli Mücadele'nin önderleri için, yukarıda ifade edilen katkıların yanı sıra sahada pratik olarak da bazı açılardan önemlidir: İngiliz ve Fransız Hükümetlerince manda idaresi altına alınması planlanan bölgelerin arasında Musul ve Kerkük gibi Misakı Milli sınırları içinde bulunan yerler vardır. Bu bölgeler sadece vatan toprağı sayıldıkları için değil aynı zamanda taktik ve stratejik değerleri nedeniyle TBMM'nin ilgi ve hedef alanlarıdır. Bu bölgeleri de kapsayacak şekilde Arap coğrafyasında koordineli şekilde yürütülecek mücadelelerin şiddeti ve başarısı, İngiltere ve Fransa'nın ilgili yerlerde daha çok askeri varlık bulundurmasına, bu sayede Anadolu'da savaşan milli güçlerin karşısındaki birliklerin zayıflamasına yol açacaktır (Yılmaz 2014: 294). Irak-Suriye coğrafyasında yerel-milli direnişin doğru yönlendirilmesi ve yönetilmesi halinde yerel hâkimiyet sağlanırsa, Türkiye'nin geliştirilen Misakı Milli'ye göre güneydoğu sınırlarının çizilebilmesi kolaylaşacak, sınır altı da güven altına alınabilecekti.

Heyeti Temsiliye ve sonrası TBMM liderliği, yukarıda değinilen yararlılıkları dikkate alarak “Arapların/yerel halkların sömürgecilere karşı bağımsızlığı” yönünde politika üretmeyi öngörmüştür. Arap coğrafyasına karşı geliştirilecek bu özgün politika, Anadolu'da bağımsız bir Türk Devleti’nin tam manasıyla kurulabilmesi esasına göre yürütülmüş, elden çıkmış ve geri dönmeyecek bölgelerde ortak düşman durumunda olan sömürgecilere karşı "Arap bağımsızlı̆̆ı" fikri desteklenmiştir. Anadolu'da 
milli devlet peşindeki liderlik için, yakın coğrafyada emperyalizme karşı yerel halkların kendi topraklarında bağımsızlığının desteklenmesi, milli devlet çabasının doğal gereği olmuştur. Çünkü sınırlar sömürgecilerden arındırılır ve tarihi dost halklar topraklarında egemen olursa, kurulacak bağımsız devletler çeşitli kardeşlik idealleri çerçevesinde uluslararası arenada gerektiğinde birbirlerini destekleyebileceklerdir.

Yukarıda tanımlanan politikaların oluşturulabilmesi ve Meclis tarafından benimsenerek resmi politikalar haline getirilmeleri için yoğun tartışmalar olmuş, değişik fikirler de ortaya sürülmüştür. Örneğin Heyeti Temsiliye'nin 23 Kasım 1919 tarihli oturumunun birinci celsesinde, milli bir meclis toplanıncaya kadar yürütülecek idare ile ilgili müzakereler yapılırken, üzerinde fikir tartışmaları olan Misakı Milli sınırları gündeme gelmiştir. Burada Mustafa Kemal Paşa Mütareke sırasındaki sınırları esas aldıklarını ancak asıl sınırların daha sonra ortaya çıkacak siyasi duruma göre belirleneceğini ve Suriye ile konfederasyonu da isteyenlerin olduğunu ifade etmiştir (İğdemir 1989: 96). Konfederasyon fikri 13. Kolordu komutanı Ahmet Cevdet Paşa'ya aittir. Mustafa Kemal Paşa'nın aktardığına göre Ahmet Cevdet Paşa'nın görüşleri kısaca şöyledir (Sonyel 1987: 152):

"Irak, Suriye, Hicaz bölgesi ve diğer Arap ülkeleri iç işlerinde bağımsız olarak, hükümetlerinin yönetimi altında olmalı. Hilafetle bağları bir konfederasyonla sağlanmalı ve Osmanlı sancağının Amerikan bayrağındaki yıldızlar gibi hükümetlerin sayısınca hilal taşımalıdırlar".

Dönemin söz sahibi isimlerinden İsmet İnönü de Araplarla Türkiye'nin ilişkileri konusunda şu kanaati belirtmiştir (Umar 2003: 62):

"Biz milli mücadeleye başladığımız zaman, Araplara karşı bütün açık yürekliliğimizle ve iyi niyetimizle ulaşmaya çalıştı̆̆ımız hedefi açıkça ve tereddüte neden olmayacak bir tarzda göstermiştik. Bizim Arap halklarının durumuna dair planımız şu idi ki, Osmanlı Imparatorluğundan çıkan Türk milleti, yüzyllarca birlikte yaşadığı, komşuluk ettiği, Araplar üzerine herhangi bir hükümranlık iddiasından kesinlikle vaz geçiyor ve Arap milletini öz vatanlarında, kendi kendini yönetebilecek yeterlilikte görüyor ve gösteriyordu."

Sömürgecilerin niyetlerinin pratik hayata tam yansımamışken, 1919'da bunların Milli Mücadele liderlerince fark edilip, kavranması ve buna karşı politikalar geliştirilmeye çalışılması ufuk genişliğini ve politikalardaki haklılı̆̆ göstermektedir.

Milli Mücadele Hükümetlerinin benimsediği ve uyguladığı politikanın ilkeleri, Mustafa Kemal Paşa'nın zihninde, muhtemelen, Birinci Dünya Savaşı sırasında Suriye coğrafyasında İngiliz ve isyancı Araplara karşı verilen cephe savaşlarında oluşmuştur. Örneğin Nablus muharebelerinde Mustafa Kemal Paşa, sayı ve güç olarak çok üstün konumdaki İngiliz ordularının şiddetli saldırıları sonucu imha edilme tehlikesi altında bulunan komutası altındaki 7. Ordu'yu önce imhadan kurtarmış ardından Anadolu'yu savunabilecek şekilde Halep'in kuzeyinde mevzilendirmiştir. Mustafa Kemal Paşa'nın bu tavrı ileride 
Anadolu'da yürütülecek bir ulusal kurtuluş savaşı konusunda henüz o dönemde bir fikri ve belki planı olduğunu göstermektedir.

Anadolu'da yeni ve tam bağımsız bir Türk devleti kurulacaksa, yakın coğrafyada yerel Arap halkları ve diğer etnik gruplar ile birlikte emperyalistlere karşı amansız bir bağımsızlık mücadelesine girmek İngiltere ve Fransa'nın oralarda etkisiz kılınması bir zarurettir. Mustafa Kemal Paşa, 28 Aralık 1919'da Ankara'da şehrin ileri gelenlerine hitap ederek, Anadolu'nun ve Arap halklarının bağımsızlık mücadelelerini övmüş, yeni gelen haberleri bildirmiş, Anadolu Hükümetinin Osmanlı Devletinden ayrı olarak uygulayacağ1 özgün siyaset hakkında bilgi vermiştir. Burada Mustafa Kemal Paşa'nın bildirdiğine göre Arap halklarının bağımsızlık taleplerine saygı gösterilecektir (Umar 2003: 262):

"Cemiyetimizin görüşüyle çizdiğimiz sınır haricinde kalan dindaşlarımızla bu muhterem kardeşlerimizle aynı sınır dâhilinde asırlardan beri vatandaşlık ettik. Bu kardeşlerimiz her tarafta Suriye'de, Irak'ta, Yemen'de, Doğu'da kendi dâhillerinde mevcudiyeti muhafaza ve bă̆ımsızlı̆̆ temin için mesai sarf ediyorlar. Bütün bu İslam parçalarının bağımsızlığa mazhar olmaları İslam âlemi için be büyük bahtiyarlı olur..."

$\mathrm{Bu}$ konuşmada söylenenler açıkça Arapların, Fransız mandacılığına karşı bağımsızlık mücadelesine verilecek desteğin ifadesidir. Anlaşılıyor ki Mustafa Kemal Paşa'nın Suriye politikası Türkiye'nin güney sınırlarının ötesinde Arap halkının kaderinin kendilerince tayinine saygı göstermek ve ama destek de olmak, onlarla iş birliğini sağlamak, böylece Fransızları iki ateş arasında bırakarak Kilikya'dan vazgeçmeye zorlamak ve bu şartlar çerçevesinde Ankara ve Fransa arasında bir barış anlaşmasını Fransızlara kabul ettirmek üzerine kurgulanmıştı (Sonyel 1987: 194 - 195).

Milli Mücadele önderlerinin Arap bağımsızlığı yönündeki kanaat ve tutumları Osmanlı Devleti Meclisi Mebusanı'na da yansımıştır, Erzurum ve Sivas Kongrelerinde geliştirilen ilkeler, 28 Ocak 1920 tarihinde görüşmeleri başlayan 17 Şubat 1920'de oylanarak kabul edilen "Misakı Milli” ile Arapların kendi geleceklerini belirleme ilkesi daha birinci madde'de aşağıdaki şekilde kabul edilmiştir (Şimşir 2006: 48):

“Osmanlı Devleti’nin, özellikle Arap çoğunluğunun yerleşmiş olduğu, 30 Ekim 1919 ateşkes (Mondros Mütarekesi) yapıldĭ̆ı sırada, düşman ordularının işgali altında kalan kesimlerin geleceğinin burada yaşayan halklarının serbestçe gerçekleştirecekleri oylama uyarınca belirlenmesi gerekir..."

\subsection{Türkiye Büyük Millet Meclisi Hükümetinin İsyancs Arap Liderlerle İliş̧ileri}

Arap isyanlarının liderlerinden Emir Faysal, İngiliz ve Fransızlarla art arda yapılan görüşmelerde, onların gerçek niyetlerini anladıktan sonra artık kendi siyasi otoritesini koruyup, sürdürebilecek iki taraflı bir siyaset geliştirmeye çalışmıştır. Emir Faysal'a, bir siyasi otorite olmak ve bundan sonra Suriye'deki Arap milliyetçilerinin politikalarına uymaktan başka yapacak bir şey kalmamıştı. Nitekim Şubat 1920’de, Emir Faysal, Arapların "tam bağımsızlı̆̆ı" Fransa'dan "kı1lıcının 
hakkıyla" kazanacağını söylemiş, hemen ardından toplanan İkinci Suriye Kongresi 8 Mart 1920' de Emir Faysal’ı Suriye Kralı olarak ilan etmiştir (Khoury 1983: 345).

Arap halklarının İngiliz ve Fransızlarca muhatap alınan liderleri 1915 yılından beri İngiltere ve Fransa gibi ülkelerle aktif işbirliği halinde oldukları için, gerek Mustafa Kemal Paşa gerekse Milli Mücadelenin diğer önde gelen liderleri, bu kişileri hiçbir zaman samimi ve güvenilir bulmamışlardır. $\mathrm{Bu}$ nedenle Arap coğrafyasında kabile ilişkili önde gelen lider durumundaki kişiler ile sivil halkı ve bunların oluşturduğu direniş teşkilatlarını birbirlerinden ayrı tutmuşlardır. Bu çerçevede ilişkiler iki farklı düzeyde kurgulanmıştır. Bu bağlamda Mustafa Kemal Paşa'nın Irak ve Suriye'den gelen direniş ve mücadele yönündeki talep ve önerilere karşı, daha ziyade alt kademeleri teşkil eden, bağımsızlık taraftarı, milliyetçi Araplar ile ayrı, hükümeti temsil eden Emir Faysal'ın elçileri yolu ile ayrı ilişkiler kurduğunu, bunlara farklı tavırlar takındığını görmekteyiz. Mustafa Kemal Paşa, Emir Faysal'a güvenmemekte, onu sömürgecilerle iş birliği yapabilir olarak değerlendirmektedir. $\mathrm{Bu}$ yöndeki görüşlerini ve güvensizliğini 29 Şubat 1920'de Talat Paşa'ya gönderdiği mektupta şöyle ifade etmiştir (Atatürk'ün Bütün Eserleri Cilt 6 2001: 407-408):

"Arap bağımsızlık hareketi karşısında başından beri savunduğumuz çözüm yolu şudur: Her millet kendi dâhilinde bağımsızlı̆̆ını kurduktan sonra konfederasyon halinde birleşmek. Bu esas Araplarca memnuniyetle kabul edilmiştir. Emir Faysal'in mutemetleri dahi biesas dâhilinde birleşmek üzere bize başvurmuşlardır. Ancak Emir Faysal'a güvenmek çok zor. Faysal'ın Fransızlar lehine gizli bir politika takip etmesi zan ve ihtimali henüz bizi ihtiyatkâr hareket ettiriyor."

Dış politikada yarar ilkesi esas alınarak Emir Faysal ile de maksatlar yönünde ihtiyatlı ilişkiler kurulmaya çalışı1ır. Bu çabaları, 9 Mayıs 1920 tarihinde TBMM’nin gizli celse oturumunda bir mebusun Arabistan bölgesindeki gelişmeler üzerine bilgi isteğine cevaben Mustafa Kemal Paşa'nın, yaptığı şu açıklamalardan anlıyoruz (TBMM Gizli Celse Zabıtları İnikat: 13, C. 3, 09.05.1920: 24):

"Suriyelilerin muhtelif merkezlerden, bizimle öteden beri anlaşmak istediklerini ve bazılarının anlaştıkları daha evvelki konuşmamda arz etmiştim. Bu meyanda Emir Faysal da vardı. Bizzat, yani Hükümet namına bizimle anlaşmak isteyen Emir Faysal bizimle daha evvel, temasa gelmeden evvel Hükümeti Merkeziye ile de Suriye Sultanı olan zatın o zaman gönderdikleri bir murahhas vardı. $O$ murahhasla görüşmüşük. Emir Faysal ve Hükümeti ve kendisi tarafindan tasdik edildikten sonra tekrar buraya sahibi salâhiyet zevatla gelmesini söyledik. Anlaşma esasları kaleme alınmış, fakat imza vazolunmamış; nevama bir müsvedde yapılmıştı. Evvelki gün Mardin'den verilen bir telgrafta o zat Iraklı Sıtkı Bey namında bir zat tekrar buraya gelmek üzere dün Mardin'den hareket etmiştir."

Henüz yazılma aşamasında olan ve olgunlaşmamış anlaşma metnini getiren Iraklı Sitkı Bey, 7 Mayıs 1920 tarihinde Mardin'den Ankara'ya doğru yola çıkmıştır. Ancak Mustafa Kemal Paşa'nın istediği gibi, ciddiye alınabilecek, imzalı yeni anlaşma metnini getirip getirmediği ve yetkili bir delege 
heyetinin Ankara'ya ulaşıp ulaşmadığı bilinmemektedir (Yılmaz, 2004). Mustafa Kemal Paşa'nın Emir Faysal'a karşı dikkatli bir tutum takındığı ama ilişkileri tamamen koparmak istemediği de açıktır.

Öte yandan, Emir Faysal cephesinde de iki yönlü niyetler güdülmüş olması mümkündür: Emir Faysal, aleyhinde bulunan milliyetçileri, Mustafa Kemal Paşa ile bir anlaşma yaptığına ikna etmek suretiyle lehine çevirmeyi ummuş olması ya da Fransızlar ve İngilizler arasında hala bir mutabakat sağlanamaması nedeniyle onları Panislamizm'le telaşlandırmaya çalışması muhtemeldir. Ama pratik hayat o kadar basit ve tek yönlü değildir. Emir Faysal'ı benimsememiş olan Fransa'nın da Emir Faysal'ın Mustafa Kemal Paşa'yla işbirliği içinde olduğunu gösterecek böyle bir anlaşma metni sayesinde İngilizleri ondan vazgeçirme fırsatı yakalamayı umut ediyor olması da mümkündür (Yılmaz 2014: 304).

$\mathrm{Bu}$ karmaşık beklentilere karşın, işlerin, doğru yorum ve değerlendirmeler sayesinde Ankara Hükümeti lehine gittiğini belirtebiliriz. Mustafa Kemal Paşa 24 Nisan 1920 günü TBMM'nin gizli oturumunda yaptığı konuşmada Türk - Arap ilişkilerinin iyiye gittiğini ve Arapların savaş sırasında Türklere karşı giriştikleri isyan hareketlerinden pişmanlık duyarak Türklerden yardım istediklerini, birlikte çözümler üretmek peşinde olduklarını aşağıdaki sözlerle açıklamıştır. İfadelere dikkat edilirse, milletlerin kendi topraklarında hâkimiyetleri esas alınmakta, ama güçlü almak ve var olabilmek için federasyon/konfederasyon gibi birlikler oluşturulmasının tartışılması gereğine dikkat çekilmektedir. Arap halklarıyla ilişkilerin de esas olarak güvenilmez yöneticileri ile değil doğrudan Arap milleti ile kurulması gereği dile getirilmektedir (TBMM Gizli Celse Zabıtları, İnikat: 2, C. 4, 24.04.1920: 1-5):

"Suriye halkı ve Irak halkı yani Arabistan, 1914 tarihinden evvel ayni ülke sinırları dâhilinde bulunduğumuz zamanlarda hepimizin bildiği gibi, Devleti Osmaniye’nin bir uzvu, bir rüknü olmaktan çıkmak, müşteki ve müstakil olmak amacı ile hareket ediyorlardı. Buna için çalıştılar, Bunun yanında bu büyük amaca ulaşabilmek için kendi güçlerinin yeterli olamayacağını kısa zamanda gördüler ve ne acıdır ki tüm İslam âlemini kontrol altına almaya hatta imhaya niyetlenen düşmanlarımızla iş birliği yaptılar. Ingilizler, Fransızlar kendilerinin hayali olan gayelerini mevkii fiile çıkaracak diye onların eteklerine sarlldılar. Lâkin savaş sona erince Suriye'de Ingilizlerin, Fransızların tarzı idaresine, muhakkirane olan idaresine şahit olduktan sonra pek büyük bir hataya duçar olduklarını gördüler ve onu müteakip bir kısmı kendi iç işlerinde bă̆ımsız olmak fakat yine bir şekilde Osmanlı birliği dâhilinde bulunmak fikrine yöneldiler.

... Tahminimce Suriyeliler herhangi bir batılı devlet ile münasebetin kendileri için kaçınılmaz bir esaret olacăğın anladılar. Bundan dolayı bize yöneldiler. Biz onlara şu şekilde karşılık vermeyi uygun bulduk. Dedik ki, artık hududu millimiz dâhilinde bulunan menabii insaniyeyi ve menafii umumiyeyi hududumuzun haricinde israf etmek istemeyiz. Fakat ittihat, kuvvet teşkil edeceğinden bütün âlemi İslam manen olduğu gibi maddeten de müttefik ve müttehit olmasını şüphe yok ki büyük memnuniyetle karşılarız ve bunun içindir ki bizim kendi hududumuz dâhilinde müstakil olduğumuz gibi, 
Suriyeliler de hududu dâhilinde ve hâkimiyeti milliye esasına müstenit olmak üzere serbest ve müstakil olabilirler. Bizimle itilâf veya ittifakın fevkinde bir şekil ki federatif yahut konfederatif denilen şekillerden birisile irtibat peyda edebiliriz. Ahali bunu arzularl lehlerine telakki etmiş olacaklar ki Emir Faysal milletin bu arzusu karşısında kendi emellerinin sarsılmakta olduğuna vakıfoldu ve müracaatları bunun üzerine oldu. Ahalinin bu arzusu fiile de inkılap etti. Suriye dâhilinde bazı ef'al ve harekât bittabi mesmuunuz olmuştur... Onun için vuku bulan siyasî müracaatta biz de siyasî cevap vermiş bulunduk. Ancak hakikî irtibat hükümet şeklinde değil fakat Suriye Milleti ile Suriyelilerle olmuş oldu ve oradaki bu hareket hakikaten bize manevi kuvvetle beraber maddî kuvvet zammetmiştir. Hududu millimizin cenup cephesindeki harekâtı nazarı dikkatten geçirecek olursak bu fiiliyatın semeratı maddiyesini görebiliriz”

Mustafa Kemal Paşa'nın yukarıda ifade ettiği gibi asıl temas bölgede Faysal hükümeti ile değil Suriye milleti ve Suriyelilerle olmuştur.

\subsection{Türkiye Büyük Millet Meclisi Hükümetinin Politik Propaganda Faaliyetleri}

Suriye coğrafyasında Fransız mandasına doğru yönelen seyri kırmak ve konu edilen politikaları hayata geçirebilmek için teşkilatlanmaları başlatabilmek üzere Ankara hükümeti bölgede yoğun bir propaganda faaliyetine girişmiştir. Milli Mücadelenin yayın organı olan Hâkimiyeti Milliye gazetesi Arap topraklarındaki olayları, direniş çabalarını hemen her gün konu ediyor, ortak emperyalist düşmanlara karşı ortak mücadele vermek gerektiğini işliyor, TBMM politikalarına uygun şekilde Arap bağımsızlık hareketini destekliyordu (Akşin 1991: 3-4).

Suriye'de yürütülen propaganda çalışmalarında, Ankara Hükümeti o coğrafyanın gazetelerini de etkin biçimde kullanmıştır. Bu yöndeki propagandalarda Suriye'de Şafak Gazetesi önemli rol oynamıştır. Gazete, Halep Heyeti Merkeziye Reisi Hilal Bey kontrolünde yayın yapmıştır (ATASE, Kls. 809, Dos. 62, Fih. 62-6).

Türkiye Büyük Millet Meclisi Hükümetinin Suriye'de doğrudan iş birliği yaptığı yayın organlarının önemli bir tanesi de Feta'l Arab (Genç Arap) dergisi idi. Derginin Türk milli mücadelesini destekleyen yayınlarında zaman zaman şu tip sloganlar kullanılmıştır: "Zafer ancak Allah katındadır”, "Vatan sevgisi imandandır", "Vatan her şeyin üzerindedir”. Feta'l Arab Dergisi'nin bir sayısinda Mustafa Kemal Paşa ismi şu sıfatlar ile taltif edilmiştir: "Türk Şevketli Milli Ordularının Başkomutanı, Anadolu'nun Kahramanı, Devletlu Müşir Gazi Mustafa Kemal Paşa”. Anadolu hareketini destekleyen yayınlar daha ziyade Beyrut'ta Emel Matbaasında basılmaktaydı. Şam'da dağıtılan bir propaganda broşüründe, Enver Paşa Mustafa Kemal Paşa’ya bir Türkiye haritası verirken gösterilmekteydi. Resmin üstünde Arapça olarak; "Büyük Kumandan Enver Paşa Türk ordusunun zaferini müteakip Gazi Mustafa Kemal Paşaya Türkiye haritası hediye ediyor” yazılıydı. Resimde dikkat çekici bir şekilde Suriye kırmızı renge boyanmıştı ve Enver Paşa açıkça eliyle burayı işaret ediyordu. Bir diğer resimde ise 
Anadolu'da Milli Mücadele saflarında savaşan Şeyh Sünusi ile Mustafa Kemal Paşa'yı ve Selahattin Eyyubi'yi Kuran-1 Kerim'i kuşatmış vaziyette gösteriyordu (Bıyıklı 2008: 331).

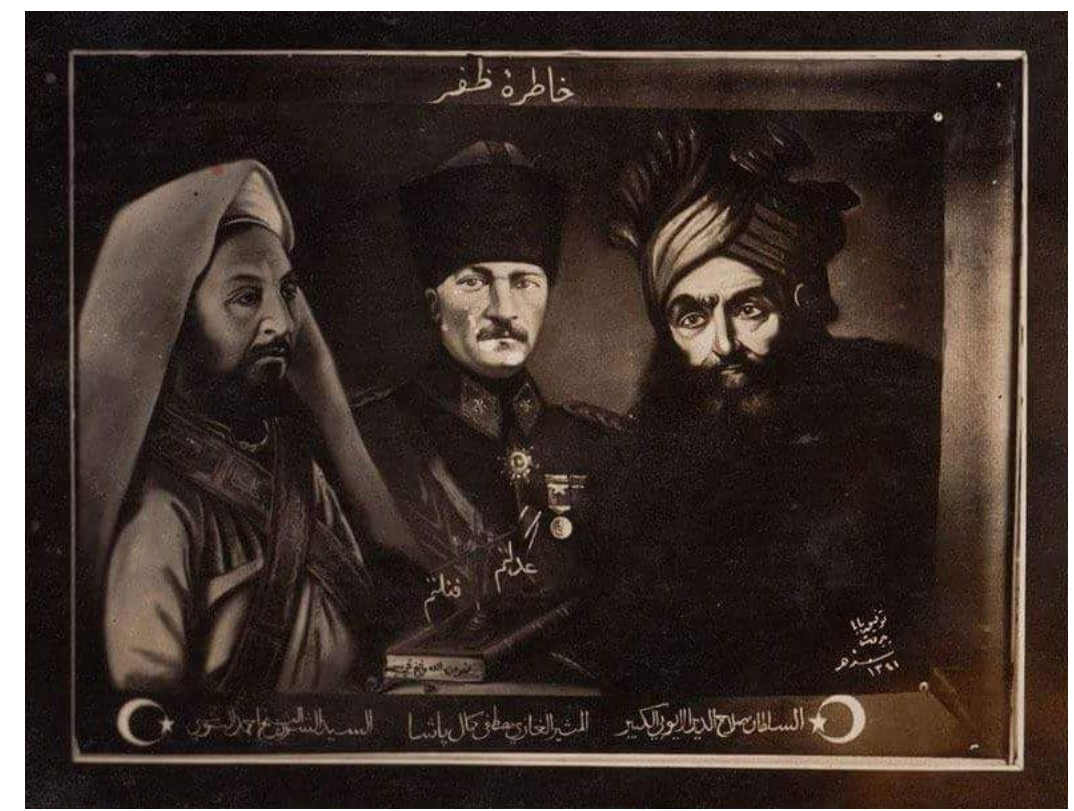

Resim: Şeyh Sünusi, Mustafa Kemal Paşa, Selahattin Eyyubi

(Kaynak: https://twitter.com/zindekultur/status/1016276394412793856)

Suriye'de sömürgecilere karşı direniş için propaganda, tanıtım ve teşkilatlanma çalışmaları sürerken Mustafa Kemal Paşa, 23 Temmuz 1919 günü Erzurum Kongresi'ndeki konuşmasında Irak ve Suriye'deki durum hakkında şu bilgileri vermiştir (Nutuk 1934: 44):

“Suriye'de ve Irak'ta İngilizlerin ve Fransızların işgal ve haksız idarelerinden tüm Arabistan galeyan halindedir. Arabistan'ın her yerinde yabancı boyunduruğuna karşı çıkılıyor. Yalnız ülkelerin gelişimi ve mutluluğu için yabancıların iktisadi, ümrani, medeni vasıtalarından yardıma izin veriliyor. Bağdat ve Şam genel toplantıları her tarafa bu kararı yaymıştır."

Nitekim Suriye'nin çeşitli şehirlerinde Fransız işgallerine karşı İslam adına cihad ve Arap bağımsızlığı için mücadele çağrıları yapılmış, Suriyelilere Anadolu'dan gönderilen bildirilerle yardımlaşmanın zorunluluğu vurgulanmıştır. Anadolu'da basılan bildiriler, broşürler, duvar ilanları Suriye'nin Halep başta olmak üzere bütün büyük şehirlerinde sürekli kullanılmıştır. Mustafa Kemal Paşa, 9 Ekim 1919'da Halep'te kurulan Kuvayı Milliye teşkilatı vasıtasıyla Suriyelilere basılı bir bildiri göndermiş, din kardeşi olarak, iki taraf arasındaki ayrılık düşüncesinden uzaklaşılmasını iki müslüman halkı birbirine düşürmeyi amaçlayan propagandalara inanılmamasını bilhassa din düşmanı Avrupalı kafirlerin yalanlarına kanılmamasını istemiştir (ATASE, Kls. 584, Dos. 8 - 141, Fih. 5-2). 
Bu dönemde, Ortadoğu'da ve Afrika'da bulunan İngiliz varlığının yönetildiği merkez olan Kahire'den 10 Kasım 1919 tarihinde İngiltere Dışş̧leri Bakanı Lord Curzon'a gönderilen bir raporda Suriye'de Türk propagandasının arttığı, yeniden Türk himaye ve sevkinin tesis edilmesinin istendiği belirtilmiştir. İstanbul'dan İngiliz yüksek komiseri Sir Robeck'in yine Lord Curzon'a yolladığı bir yazıya Halep'te dağıtılan ve Mustafa Kemal Paşa'nın sözlerini içeren bir beyanname eklenmişti. Beyannamede kısacası şu ifadeler bulunmaktaydı (Bıyıklı 2008: 328):

"Kederli bir milletin sesine kulak ver, despotizmin ellerine düşme, düşmanlarının kötü emellerine kapılma, Türklerle Araplar arasında sokulan nifaklara aldırma. Kanma. Hainlere karşı birleş. Sonra pişman olursun. TBMM hükümeti vatanı, milleti ve müslümanları Kurtarmak istiyor. Din kardeşleri olarak yaşayalım, düşmanlarımızı kahredelim".

Mustafa Kemal Paşa'dan ve diğer TBMM Hükümeti yetkililerinden Suriye'de bulunan direniş liderlerine ve halka yönelik mektup ve bildiriler Suriye'de Fransa'ya karşı mücadele sürdügü müddetçe gelmeye devam etmiştir (Şimşir 2000: 192).

İşgalcilere karşı yürütülen propaganda faaliyetleri boyunca Suriye'deki Arap ve Türklerin yanı sıra Fransız ordusunda görev yapan Tunuslu, Faslı, Cezayirli ve Afrika'nın diğer bölgelerinden gelen Müslüman askerlere de ulaşılmaya çalışılmış, bu maksatla Arapça ve Fransızca hazırlanan bildiriler kullanılmıştır. Gösterilen çabalar belirli ölçüde yarar da sağlamıştır. Nitekim bazı Müslüman kökenli Fransız askerlerinin üstlerine itaatsizlik gösterdikleri, din kardeşlerine karşı silah kullanmak istemedikleri görülmüştür (Çolakoğlu 1991: 124 - 125). Şüphesiz bu durum Fransız ordusu yönetim kademelerinde önemli bir güven ve moral kaybına, ciddi kaygılar doğmasına neden olmuştur.

Ankara Hükümeti, geliştirdiği politikaların sahadaki gereklerini yerine getirebilmek, pratiğe aktarabilmek için uyguladığg yoğun propaganda faaliyetleri ile yöre halkının, Türkmenlerin, Arapların bağımsızlık ve özgürlük heyecanları arttırılıp, Anadolu direnişi ile irtibat sağlayacak psikolojik zemin oluşturulmaya çalışılmıştır. Aynı anda fiilen Suriye ve Irak’ta direniş örgütleri kurulmaya, irtibat görevlileri oluşturulmaya, Arap direnişçileri örgütlenme ve yönlendirilmeye başlanmıştır.

\subsection{Suriye'deki Yerel Direniş Örgütleri}

Mondros mütarekesinin son derece olumsuz sonuçlar doğurabilecek maddelerinin anlaşılmasından sonra, Anadolu'da henüz işgal edilen veya işgal tehlikesi altında olan bölgelerde yaşayan Türk halkı en azından çiftliklerini, köylerini, kasabalarını koruyabilmek için silahlanma yoluna gitti. Kuvayı Milliye'nin ilk unsurları böyle doğdu. Bu ilk unsurlar arasında herhangi bir eşgüdüm, lider kabul ettikleri bir merkezden aldıkları emirler ile hareket etme gibi koordineli ve ortak disiplinli faaliyetler söz konusu değildi. Bunlar, tamamı ile Türk halkının, en azından yaşadığı toprakları koruyabilmek amacıyla kendiliğinden oluşturduğu direniş yapılarıydı. 30 Ekim 1918 sonrasındaki bu gelişmeler, çoğunlukla İstanbul'da faaliyet gösteren işbirlikçi bazı örgütlerin düşüncelerinin aksine, 
Türk milletinin köyünü, kasabasını, toprağını, vatanını koruyabilecek azme, iradeye ve cesarete sahip olduğunu açıkça gösteriyordu.

Anadolu'nun hemen her yerinde ortaya çıkmaya başlayan bu unsurlar, Temsil Heyeti'nin, ardından TBMM Hükümetlerinin gayretleri ile kısa süre içinde koordine olmaya, işgalcilere karşı direniş ve vatanı savunma hedefleriyle Milli Mücadele'nin merkezi iradesi yönünde teşkilatlanmaya ve hareket etmeye başladı. Güney Anadolu da bu teşkilatlanmaların güçlü ve etkin olduğu bölgeler arasındaydı.

Kilis, Aralık 1918'de İngilizler tarafından, 1 y1l sonra, 29 Ekim 1919'da da Suriye İtilafnamesi ilkelerine göre Fransızlar tarafından işgal edilmiştir. İşgale karşı Kilis’te Askerlik Şubesi merkez olmak üzere bir direniş örgütlenmesi oluşturulmuş, kurulan Kilis taburunun komutanlığını da Askerlik Şubesinin o dönemki başkanı yapmıştır. (Şahin 2014: 281). Mütarekeden sonra yurda dönen başarılı subaylardan biri olan Üsteğmen Mehmet Sait Bey “Şahin Bey” adı ile Antep Müdafaa-i Hukuk Cemiyeti kararıyla Kilis ve Havalisi Kuvayı Milliyesi Komutanlığına atanmış, takiben Kilis Taburunun komutasını devir almıştır (Çolakoğlu 1991: 124). İşgal güçlerine karşı Antakya'da da ilk teşkilat Eylül 1919'da Hocazade Yüzbaşı Asım Bey ve Dedebeyzade Hakkı Bey önderliğinde 10 kişilik bir gönüllü grubu tarafından oluşturulmuştur. Bu grup ilk silahlı eylemini Kasım 1919'da, Suriye coğrafyasında, Kuseyr'de yapmıştır ${ }^{4}$ Fransızların Antakya'ya yerleşmesi sonrasında, 13 Kasım 1922 tarihinde, bu Kuvayı Milliye örgütlenmesi Antakya içindeki Fransız kışlasına ani bir baskın yaparak, kısa süre için de olsa şehrin kontrolünü ele geçirmiş, dahası hapishanelerde Fransızlarca esir tutulanları da kurtarmayı başarmışlardır (Yılmaz 2017: 388 - 389).

Türkiye Büyük Millet Meclisi’ nin açılmasından sonra Anadolu'daki direniş çok daha yaygın, koordineli ve etkili hale gelirken, TBMM hükümetleri, sadece Anadolu ile değil, eski Osmanlı Devleti toprağı olan yakın coğrafya ile de ilgilenmişlerdir. Özellikle Suriye, Anadolu'daki hareketin başarıya ulaşması için en kritik önemdeki bölgelerden biri olduğundan, bu bölgede TBMM Hükümetinin denetiminde güçlü bir Kuvayı Milliye organizasyonuna ve bunun güçlü ve etkili mücadelesine ihtiyaç duyulmuştur.

Kuzey Suriye'de yüzyıllar boyunca devam eden Türk hâkimiyeti ile Türk ve Türkmen nüfusun çoğunlukta olduğu pek çok bölge oluşmuştu. Halep’ten itibaren Türkiye sınırına kadar Suriye coğrafyasının kuzey kısmında hâkim olan çoğunluk Türkler idi, Halep, adeta bir Türk şehriydi. (Akbıyık, 1970: 93 -94). Söz konusu nüfus yapısı, Suriye kuzeyinde Kuvayı Milliye teşkilatlanmasını kolaylaştırmıştır. TBMM Hükümeti de Türk unsurların yoğun bulunduğu bölgelerde ilk örgütlenmeleri bizzat başlatmış ve yönetmiştir. Nitekim Kilis’te oluşturulan Kuvayı Milliye, teşkilatlanmasını Kuzey Suriye içlerine kadar hızla genişletmiş; Hassa, Reyhaniye, Beylan ve Menbiç kazalarında birer Müdafaa-i Hukuk örgütlenmesi kurulmuş, bunlar Halep ve Şam başta olmak üzere Kuzey Suriye şehir

\footnotetext{
${ }^{4}$ Halep'in yaklaşık 190 km güneyinde Humus - Lübnan arasında bir kasaba. Fransız birliklerinin Antakya bölgesine ulaştırılması için önemli bir istasyona sahipti.
} 
ve kasabaları ile sürekli irtibat halinde olmuşlardır. Suriye Kuvayı Milliye teşkilatları içinde, öncelikle bölgede yaşayan Türk-Türkmen nüfus ön planda rol oynasa da, zaman içinde, Ankara Hükümetlerinin politikaları ile bağımsızlık yanlısı Arap milliyetçiler ve Osmanlı Devleti'ne bağlılığını sürdüren Arap kökenli subaylar da bu teşkilatlara katılmıştır (Çolakoğlu 1991: 74).

Mustafa Kemal Paşa, TBMM adına, çok önem verdiği Kuzey Suriye'de yerel milli teşkilatlanmayı geliştirmek ve yönetmek üzere Antep Kuvayı Milliye Komutanı Ali Şefik (Özdemir) Bey’i bizzat görevlendirmiştir5 (Güner, 2007: 49 - 65; ATASE, Kls. 599, Dos. 9 - 154, Fih. 1). Ali Şefik (Özdemir) Bey, anılarında Kuzey Suriye'de bir Kuvayı Milliye Teşkilatı oluşturulması görevini ve konu ile ilgili aldığı diğer talimatları bizzat Mustafa Kemal Paşa'dan aldığını ve ona göre hareket ettiğini anlatmaktadır (Göztoklusu, 2010: 39).

Özdemir Bey, Birinci Dünya Savaşı sırasında Osmanlı ordusunda hizmet etmiş bir subaydır. Mondros Mütarekesi'nin imzalanması sonrasında Suriye'de kalmayı tercih etmiş, ancak Anadolu'daki gelişmeleri yakından takip etmiş, orada başlayan direniş örgütlenmesi ile bağlantı kurmuştur. Ali Şefik Bey, Temsil Heyeti'nden aldığı talimatlar doğrultusunda, 2 Şubat 1919 tarihinde Türk Arap Muhadenet Cemiyeti' ni (Türk - Arap Dostluk ve Dayanışma Derneği) kurmuştur. Teşkilatın isminden Türk ve Arapların ortak düşmana karşı yürütülen mücadelede birlikte hareket etmelerinin teşvik edileceği anlaşıılmaktadır. Bölgede Özdemir Bey tarafından kurulan gizli teşkilatlardan biri de yine 1919 yılında kurulan Suriye ve Filistin Müdafaa-i Kuvayı Osmaniye Heyeti' dir. Bu Heyet'in Genel Başkanı Özdemir Bey’di. Kısaca adına "Suriye Heyeti Milliyesi” diyebileceğimiz bu teşkilatın Halep’te bulunan yöneticisi de Hilal Bey idi. Teşkilatın askeri konulardaki liderliğini ise Natık Bey yapıyordu (Umar, 2004: 428).

Teşkilatlanma gereği, Özdemir Bey, görevini, Anadolu'daki teşkilatlarla ve Ankara Hükümetleri ile koordineli bir şekilde gerçekleştirebilmek üzere, Maraş'ta bulunan 2. Kolordu'nun komutanı Selahattin Adil Bey ile sürekli temas halinde olacaktır. Özdemir Bey tarafindan Kuzey Suriye'de oluşturulacak teşkilatlanma ile Anadolu'daki teşkilatlanma arasındaki iletişimi 2. Kolordu Komutanı Selahattin Adil Bey sağlayacaktır. (Yorulmaz, 2005: 352; Umar, 2004: 429).

Özdemir Bey tarafından örgütlenen Suriye teşkilatlanmasının genişletilmesi, mücadele gücünün arttırılması için hem yerel alanda görev alanlar hem Anadolu'da irtibatta olunan görevliler hem de TBMM Hükümeti tarafından oldukça önemli çalışmalar yapılmış, teşkilatlanmanın daha da yayılması ve halkın desteğinin sağlanması için pek çok tedbir alınmıştır. Genel olarak halkın teşkilat mensuplarından hiçbir zarar görmemeleri, bölgelerarası ulaşımın sekteye uğramaması, ziraata uygun ortam sağlayarak açlığın ve sefaletin engellenmesi bu tedbirler arasında sayılabilir. Böylece Türk, Arap, Kürt halklarının desteği de zaman içerisinde gittikçe güçlenmiştir. Sosyal nizamı sağlamak için Müdafaa-i Hukuk Derneklerinin faaliyetleri ile bölgede Osmanlı Devleti'nin bürokratik varlığı adeta

\footnotetext{
${ }^{5}$ Asıl adı Ali Şefik Bey olup, “Özdemir” bir takma ad olarak kullanılmıştır.
} 
devam ettirilmeye çalışılmıştır. Bu sıralarda önce İngilizlere ardından Fransızlara karşı sürdürülen çatışmaların da ardı arkası kesilmemiş, yerel halka güven, cesaret ve umut verilmiştir. Bütün bu gayretler neticesinde Suriye Heyeti Milliyesi kısa süre içinde yayılarak, Şam, Halep, Humus, Beyrut, Hama, Lazkiye, Trablusşam, Baalbek ve Kuneytra'da Anadolu coğrafyasında oluşturulan teşkilatlara benzer şekilde Kuvayı Milliye şubeleri açmıştır (Umar 2004: 428; Sonyel 1972: 190; ATASE, Kls. 599, Dos. 29 - 154, Fih. 1-3; Gn. Kur. Bşk. Türk İstiklal Harb. Gün. Cep., 1966: 21; Umar 1999: 87- 96).

Teşkilatlanma sürdürülürken propagandaya da büyük önem verilmiştir. Türkçe, Arapça, Fransızca olmak üzere 3 dilde hazırlanan beyannameler, başta Suriye sınır kesimi olmak üzere Şam, Halep ve Suriye'nin diğer kısımları ile Fransız karargâhlarına dağıtılmıştır. Bu şekilde Fransız ordusunda görev yapan Tunus, Fas, Cezayir gibi ülkelerden gelen Müslüman askerler etkilenmeye çalışılmıştır (Umar 2004: 429).

Teşkilatlar, daha önce de değinildiği üzere sadece Türklerden oluşmuyordu. İngiliz ve Fransızların Suriye'yi parçaladığını gören Arap milliyetçileri, hatta Emir Faysal hükümetinde önemli görev alan bazı kişiler de Suriye Kuvayı Milliye organizasyonu için de görev almış, en azından destek vermişlerdir. Bunlar arasında Şeyh Kamil Kassap, Binbaşı Muhittin Bey, Said Bey, Dr. Alâeddin Şehbender gibi önemli Arap milliyetçilerinin yanı sıra, Emir Faysal'ın yönettiği Suriye Krallığı Arap Hükümeti Savunma Bakanı Abdülhamit Paşa, Savunma Bakanı Müsteşarı Mustafa Nimet Bey, Adliye Bakanı Celal Bey, Eğitim Bakanı Haşim Bey gibi önemli kişiler de bulunuyordu. Kuvayı Milliye Teşkilatı içerisinde pek çok aşiret de görev almıştı. Hadidi aşireti reisi Şeyh Faris, Mevali Aşireti Reisi Abdülkerim Paşa, İbni Reşit Aşireti Şeyhi İbni Süleyman bunların önde gelenleriydi. Kuzey Suriye eşrafından da pek çok kimse de teşkilatta görev almıştı. Bunların yanı sıra gazeteciler ve aydınlardan da temsilciler bulunuyordu. Fransızların Suriye'de Ermenilerden gönüllü asker olarak istifade etmeleri Arapların Fransızlara olan karşıtlığını keskinleştirmiştir (Umar 2004: 430; ATASE, Kls. 1690, Dos. 240 -463 , Fih. 1-3).

Silahlı direniş amacıyla kurulan bu tür teşkilatlar dışında, özellikle Suriye'de halka yönelik propaganda çalışmaları yapmak amacıyla, İstiklal, Doğu Milletlerine Yenilik, İslam Cemiyeti gibi daha ziyade propaganda unsurları ile mücadelesini sürdüren yapılarda oluşturulmuştur (Bıyıklı 2008: 325). Propaganda faaliyetleri içinde gazetecilerden ed - Defa Gazetesi sahibi Tevfik Yazıcı, Müfid Gazetesi sahibi Yusuf Haydar Bey, eş Şaab Gazetesi sahibi el-Esad ve Hedef Gazetesi sahibi Abdül Hayr Bey teşkilatlanmada yer alarak, propaganda ve tanıtım görevleri yapmışlardır (Umar 2004: 430).

Türkiye, Suriye'deki Kuvayı Milliye yapılanmasının sadece koordinasyon, silah ve cephane ihtiyaçlarını değil, teşkilat mensuplarının bazı özel ihtiyaçlarının karşılanması için de elinden geldiğince bölgeye parasal destek sağlamıştır. Haziran 1920'de Suriye'deki Kuvayı Milliye teşkilatı tarafından yazılan bir raporda, teşkilata bağlı olup da mücadele halinde iken tutuklanan Kaymakam Sami Bey, Arnavut Muharrem Nuri Bey ve Mustafa Sabri Beylerin özellikle ailelerinin ihtiyaçlarının karşılanması 
için belli bir tahsisat talep edilmiştir. Osman Umar'ın belirttiğine göre bu ailelerin maddi ihtiyaçları Anadolu'daki Milli Hükümet tarafından tahsis edilen bir para ile karşılanmıştır (Umar 2003: 34).

Suriye Heyeti Milliyesi'nin Halep'deki lideri (Halep Heyeti Merkeziye Reisi) Hilal Bey, 1921 Ocağında Özdemir Bey'e gönderdiği bir raporda, Emir Faysal liderliğindeki Şam Arap hükümetinin henüz kurulmakta olan Suriye Arap ordusunda büyük bir düzenleme yaptığını, mevcut subayların çoğunun kadro dışı bırakıldığını belirtmiş, yaklaşık 176 subayın açıkta kaldığını ifade etmiştir. Bunlar içinden Kuvayı Milliye’ye hizmet etmek azminde olanlar olduğunu belirtmiş, ancak bunların maddi ihtiyaçlarının karşılanması gerektiğini vurgulamıştır. Bunlar içinde en güvenilir kimselerin Suriye Kuvayı Milliye teşkilatına alınabilmesi için parasal desteğin artırılması gerektiğini ifade etmiştir. Özdemir Bey bu bilgiler üzerine bizzat TBMM'ne müracaatta bulunarak yeteri kadar subayın istihdam edilmesi için parasal destek talebinde bulunmuştur. Konu ile ilgili Erkan'ı Harbiye Riyaseti, Suriye'deki teşkilatlanmanın sorumlu amiri konumundaki 2. Kolordu Komutanı Selahattin Adil Bey'den konu ile ilgili bilgi istemiştir. 2. Kolordu Komutanlığı'ndan Özdemir beyin istekleri hakkında olumlu görüş gelmesi üzerine, Erkan'ı Harbiye Riyaseti, Özdemir Beyin Suriye'deki Kuvayı Milliye Teşkilatını güçlendirmesi için 2. Kolordu'ya 5,000 lira para tahsis ettiğini bildirmiş, 2. Kolordu Komutanı bilgiyi hemen Özdemir Bey’e iletmiştir (Umar 2003: 35). Sonuçta, Suriye'deki Kuvayı Milliye organizasyonu, hemen tamamı Osmanlı askeri okullarında eğitilmiş ve Birinci Dünya Savaşı'nda büyük tecrübe kazanmış bu subayların katılımı ile taktiksel düzeyde yeterliliğini ve kabiliyetini büyük ölçüde artırmıştır. Artık Suriye coğrafyasında Anadolu ile koordineli direniş̧ operasyonları daha iyi planlanmakta ve icra edilmektedir.

\subsection{Suriye Topraklarında Sömürgecilere Karşı Direnişin Merkezi Halep}

Fransa'ya karşı Suriye'de yürütülen direnişin merkezi Halep'ti. Halep, aslında Anadolu'nun ayrılmaz bir parçası olarak görülüyordu, hatta bir dönem Misakı Milli sınırları içerisinde dahi kabul edilmişti. Halep ve çevresi, Milli Mücadele güçlerinin ve onlarla birlikte hareket eden milliyetçi bağımsızlık yanlısı Arapların teşkilatlanma ve koordinasyon zeminini oluşturmuştur. O yıllarda Halep bölgesinde Türkmenler yoğun olarak bulunmaktaydı, ancak Arap dünyasının iyi yetişmiş, yüksek tahsilli insanları da Halep'te yaşamayı tercih ediyorlardı. Nitekim Halep'te yaşayan Araplar arasında Arap milliyetçiliği ve bağımsızlık heyecanı oldukça güçlüydü. Mustafa Kemal Paşa, bu bölge üzerinde hassasiyetle durmuş, hem Türk hem Arap liderlere gönderdiği mesajlar ile ortak hareketi ve işbirliğini geliştirmeye çalışmıştır. Halep’te Türkler ve Araplar tarafından, kimisi müştereken, kimisi ayrı ayrı pek çok silahlı, silahsız direniş teşkilatları kurulmuştur.

Halep merkezli direniş örgütleri çoğunda Türk ve Arap subaylar birlikte görev yapmışlardır. Halep ve çevresinde Fransızlara karşı ciddi bir mücadele yürüten Kuvayı Milliye unsurlarından birinin lideri Arap asıllı emekli subay Şakir Nimet Bey'dir. Şakir Nimet Bey, Necati Cemiyeti Vataniye adlı bir teşkilat kurmuştur (Çolakoğlu 1991: 129-134; Selek 2002: 390). Bu cemiyet her ne kadar kadro 
olarak bünyesinde daha ziyade Araplara yer verse de, Suriye Filistin Müdafa-i Kuvayı Osmaniye Heyeti'nin alt şubesi olarak görev yapmıştır. Mustafa Kemal Paşa Suriye ile ilgili kritik konularda Arap asıllı Şakir Nimet Bey'in düşüncelerine ve bilgilerine büyük değer vermiş, Şakir Nimet Bey ve Mustafa Kemal Paşa arasındaki iletişim uzun bir süre devam etmiştir. (Çolakoğlu 1991: 129 - 134).

Antep, Maraş, Urfa, Adana illerimizdeki Kuvayı Milliye teşkilatlarının önemli isimlerinden biri olan Polat Bey, aynı zamanda Halep merkezli Suriye teşkilatları ile de ortak çalışmalar yapmış ve iki taraf arasında iş birliğini sürekli canlı tutmaya çalışmışır. Suriye'deki direnişin sertliğinin, Anadolu'da Kuvayı Milliye güçlerinin işini kolaylaştıracağını öngörenlerden birisi de Polat Bey'dir. Ama Polat Bey'in, Suriye'deki direnişin başarıya ulaşacağına, bölgenin bağımsız yerel bir iradeye sahip olabileceğine olan inancı da tamdır. O’na göre Kuzey Suriye'deki Kuvayı Milliye teşkilatlarının Anadolu'yu kurtarmak için sadece bir araç olarak kullanıldığı fikri gerçeği yansıtmamaktadır.

Polat Bey anılarında Suriye'deki mücadeleden şu sözlerle bahsetmektedir (Umar 2004: 429):

"Halep ve oradaki teşkilatın gerçekleştirdiği faaliyetler ve Türk Kuvayı Milliyesine olan yardımları gerçekten çok büyüktür. Halep'teki teşkilat Tıpkı Türkiye'deki teşkilat gibi gece gündüz bütün gayretiyle çalışmış, bizi azami ölçüde desteklemiştir”. Bu çalışmaların semeresi olarak, Hassa, Reyhaniye, Belen, Menbiç kazalarında birer Kuvayı Milliye Teşkilatı vücuda getirilmiştir. Ayrıca bu organizasyon Suriye'deki tüm kasaba ve kentlerle temasa geçmiş. Onların da Mücadele'ye desteğini elde etmeye çalışmıştır. Halep'teki teşkilatımız Suriye'deki en önemli şahıslar tarafindan bizzat desteklenmiştir".

Milli Mücadele Hareketi için Suriye'de yürütülen mücadelenin ve Halep kentinin konumunun önemini Heyeti Temsiliye Reisi Mustafa Kemal Paşa ve Batı Anadolu Kuvayı Milliye birliklerinin komutanı Ali Fuat Paşa yayınladıkları 24 Ocak 1920 tarihli genelge ile şöyle ifade etmişlerdir (Atatürk’ün Bütün Eserleri 1991: 135):

“Suriye'de Faysal hükümetinin tünel büyüklüğünde bir Askeri Birliği vardır. Bu birliğin büyük kısmı Halep ve Müslümiye arasında karargâh kurmuş durumdadır. İskenderun'da bazı bulunmaktadır. Vilayetinin önemli bir klsmında Arap halk ve bürokrasi Camiya-i Osmaniye'den ayrllmak niyetinde değildir. Ama işse mücadele etmek için güçlü ve kararlı bir teşkilat vücuda getirmişlerdir. Bu teşkilatın bizimle birlikte hareket etmek isteyeceğini tahmin ediyoruz. Bu nedenle teşkilat liderleri ile çeşitli yollardan temas sağlanmıştır. Halep'teki milli direniş teşkilatının liderlerinden biri Kaymakam Emin Bey iken, bir diğeri Halep polis müdürü Şakir Nimet beydir."

Halep ve çevresinde kurulan direniş teşkilatlarının önemli bir kısmı Anadolu ile ortak hareket etme düşüncesinde iken bazı teşkilatlar, TBMM' nden uzak durmayı tercih etmişlerdir. Bu teşkilatlar, Ankara Hükümeti'nin Suriye'deki direnişi kendi amacı için ve Suriye'yi hedeflediği kendi devlet sınırlarına katma maksadına yönelik kullanmakla suçlamışlardır (Tekin, 1993, s. 340, Şimşir 2006: 189). 


\subsection{Anadolu Direnişi İle Suriye Direnişi Arasında Sahada Yaşanan İlişkiler}

Anadolu ile birlikte Suriye'de başlayan, Anadolu teşkilatları ile koordineli ve çoğu zaman birliktelik içinde yürütülen Halep merkezli direnişin yarattığı etki, beklendiği üzere hem Anadolu direnişi için hem de Suriye coğrafyasındaki bağımsızlık çabaları için önemli faydalar sağlamıştır. Anadolu'da, Suriye coğrafyasına yakın olarak görev yapan TBMM' ne bağlı askeri birlikler, ellerindeki tüm imkânları kullanarak, Fransızlara karşı yürütülen direnişin güçlenmesi ve devamı için oluşturulan teşkilatlara yardımlar yapmak üzere, büyük gayret ve fedakârlıklar göstermişlerdir.

O tarihlerde sınırların iç içe geçtiği Antakya'da ilk teşkilatlı mücadele Mayıs 1919'da başlar. Şehirdeki Türk Kuvayı Milliye hareketinin mensupları, kendini birleşik Arabistan'ın hâkimi olarak gören ve bunun için mücadele eden Şerif Hüseyin adına Arapça okunan hutbeyi Türkçe okuturlar. Eylül 1919'da Hocazade Yüzbaşı Asım Bey ve Dedebeyzade Hakkı Bey'le 10 kişi Halep'e gidip, cephane ve silah mühimmat yardımı alırlar (Umar 2004: 431). Kısa zamanda başarıyla gerçekleştirilen bu örgütlenme ile Antakya bölgesinde Fransızlar üzerinde ciddi bir baskı oluşturulur.

Anadolu ve Suriye arasındaki iletişimi ve lojistiği sağlamakla görevli olan 2. Kolordu Komutanı Selahattin Adil Bey, Halep, Hama, Lazkiye, Samandağ, İskenderun ve Kırıkhan sınırları içinde kalan bölgede gizli bir teşkilat oluşturmuştur. Teşkilat, Fransız birliklerine karşı yapılan baskın ve saldırılarda Fransız Birliklerinin terk ettiği önemli miktarda cephanenin ele geçirilmesinde, önemli bazı kişilerin güvenle Suriye - Anadolu - Suriye arasında seyahat etmelerinde görev yapmıştır. (ATASE, Kls. 599, Dos. 29 - 154, Fih. 21).

Suriye'de faaliyet gösteren Kuvayı Milliye'nin faaliyetlerine bölgedeki aşiretler de zaman zaman katılıyordu, Barak ve Reşi aşiretleri tam olarak Kuvayı Milliye den yanaydı (Özçelik 1992: 215). Aşiretlerin bir kısmı Halep Heyeti Merkeziyesi Reisi Hilal Beyin denetimi altında faaliyet göstermişlerdir. Cebeli Zaviye ve İdlib Bölgesi'nin durumu, buralardaki aşiretlerin tutum ve faaliyetleri hakkında, bu aşiretlere mensup önemli bir isim olan Süleyman Bey, Halep Heyeti Merkeziye lideri Hilal Bey’e düzenli olarak rapor vermiştir (ATASE Arşivi, Klasör No: 1168, Dosya No: 52 - 3, Fihrist No: $24-1)$.

Türk ve Arap işbirliği sahada arttıkça Suriye-Anadolu direnişi daha da koordineli hale gelir. Türk ve Arap ortak direnişinin oldukça güçlü gerçekleştiği yerlerden biri de Resulayn ${ }^{6}$ kazasıdır. Türklerin çoğunlukta olduğu kasaba, Birinci Dünya Savaşı'nın bitimini takiben Arap ve müttefik ordularınca saldırıya uğramış, ancak Resulayn halkı güçlü bir direniş sergileyerek işgali önlemiştir. Gelişmeler Resulayn ileri gelenlerince 14 Kasım 1919'da Sivas Müdafaa-i Hukuk Başkanlığına yazılan telgrafla bildirilmiştir (Umar 2004: 430). Resulayn halkı, Suriye direnişine 500 kadar piyade ve süvariden oluşan bir kuvvet toplayarak mücadeleye aktif olarak katılmıştır (Özçelik 1992: 95).

\footnotetext{
${ }^{6}$ Türkiye - Suriye sınırı üzerinde, bugün Türkiye’ye bağlı Ceylanpınar ilçesinin hemen karşısında bir kasaba.
} 
Direnişin örgütlenmesinde ve başarısında daha önce değindiğimiz gibi bölgede doğup büyümüş Türk - Arap subayların önemli katkıları olmuştur. Suriye Kuvayı Milliye teşkilatı ile çalışan Arap subaylarının en ünlülerinden biri Yasin El Haşimi' dir $^{7}$ (Umar 2004: 293). Yasin El Haşimi, Aralık 1919'da Halep'ten aldığı talimat doğrultusunda 2,000 adamıyla Deyr-i Zor'a ${ }^{8}$ saldırmış ve buradaki İngiliz - Fransız birliklerine ağır kayıplar verdirmiştir. Emir Faysal'ın en güvendiği destekçilerinden biri olan Emir Zeyd ${ }^{9}$ adeta Kuvayı Milliyeci gibi davranmış, Deyr-i Zor saldırısına katılanları 12,000 Türk Lirası ile ödüllendirmiştir.

9 Haziran 1920'de, Suriye ve Filistin Müdafaayı Kuvayı Osmaniye Heyeti Başkanı Özdemir Bey tarafından yazılan bir rapora göre, Türk taraftarı Kaymakam Ali Hulki Bey idaresindeki Amman, Kuneytra Çerkezleri, Merciuyyun Havzasını idare eden Emir Mahmud el Fuad, Havranlılar ve Revale aşireti Fransızlara ağır darbeler indirmeyi başarmışlardır (Evans 1972: 240 - 255).

Fransızların Suriye içindeki garnizonlarından çıkıp, kritik bölgelere ulaşamamaları, böylece alan hakimiyeti sağlayamamaları Kuvayı Milliye güçleri için önemli bir amaçtı. Araştırmacı Ali Saip’e göre Urfa'daki Müdafaa-i Hukuk Heyetine, 13 Şubat 1920 tarihinde Birecik'teki Kuvayı Milliye Birliği'nden gelen bir rapora göre, Fransızların Suriye - Anadolu - Suriye arasından karşılıklı olarak askeri sevkiyatlarının engellenmesi amacıyla Akçakoyunlu istasyonundan Suriye içlerine uzanan demiryolu raylarının sökülüp saklandığı ve ayrıca Sacur köprüsünün tahrip edilerek, trenlerin geçmesine engel olunduğu ifade edilmiştir (Saip 1340: 119 - 120). Kuvayı Milliye mensuplarının demiryolu sabotajları ve saldırıları sürekli tekrarlamıştır. Suriye ve Anadolu arasında demiryolu ulaşımını sağlayan Katma - İslahiye Demiryolu hattına Türk ve Arap direnişçiler pek çok saldırı ve sabotaj düzenlemişlerdir. (Çolakoğlu 1991: 74 - 106). Kesintisiz devam eden baskınlar, sabotajlar ve saldırılar ile Fransız ordusu sadece hareket kabiliyetini kaybetmiyor, aynı zamanda olduğu yerde meşgul ediliyor, önemli bir kuvveti bölgede hareketsiz tutması sağlanıyordu. Ayrıca Fransız ordusunun Güney Anadolu'ya nakli engelleniyordu. Fransızların - Halep demiryolunu kullanmalarının olabildiğince engellenmesi sahile yakın bölgelerde kuşatılan Fransız garnizonlarının karadan ikmal edilmeleri ve destek almalarını zorlaştırıyor, Fransızlar sadece deniz yolunu kullanmaya mecbur kalıyorlardı (Fromkin 1993: 436). Bu sayede hareketsiz kalmaya zorlanan Fransızlar, Türkler ve Araplar tarafindan iki ateş arasında bırakılmış, kısa zaman içinde Halep'in doğusunda, Sefire ve Garbize'de, İdlib, Cebeli

\footnotetext{
${ }^{7}$ Suriye'de görev yapan 12. Kolordu'nun kurmay başkanlığını yapmıştır. Daha sonra bağlılığından şüphelenilerek, İstanbul'da cephe gerisi bir göreve atanmıştır. Yasin El Haşimi daha sonra Galiçya cephesinde görevlendirilmiş, ardından Filistin Cephesinde 8. Kolordu komutanı olmuştur. Savaş sonuna kadar Osmanlı Devletine bağlı kalmıştır. Savaştan sonra da Suriye'de Milli Mücadele yanlısı olarak çalışmış önemli bir Arap kökenli askeri liderdir. Yasin El Haşimi 5 Ekim 1918'de Emir Faysal tarafından kurulan hükümette Savunma Bakanı olarak görev almıştır. Aslen Iraklıdır. 2005 yılında Irak Parlamentosunda Sünni grubun liderliğini ve Irak Devlet Başkanı Yardımcılığını yapan Tarık El Haşimi’nin büyük dedesidir. Tarık El Haşimi halen Türkiye'de yaşamaktadır.

${ }^{8}$ Suriye'nin orta batısında Fırat nehri kıyısında bir kasaba.

${ }^{9}$ Bağımsızlık yanlısı Suriyeli Arap milliyetçi lider. Suriye'de krallığını ilan eden Emir Faysal tarafından Suriye İdareciler Meclisi başkanlığına atanmıştır.
} 
Zaviye, Cisri Şugur, Harim, Antakya, Lazkiye, Rakka, Menbiç ve diğer noktalarda Fransızlar oldukça zor durumlara düşmüşlerdir (ATASE, Kls. 599, Dos. 29 - 154, Fih. 35).

Başarılı bir direniş için Fransız hareketliliği demiryollarının yanı sıra karadan da kısıtlanmalıydı. Türk Genelkurmayı ile Suriye'deki Kuvayı Milliye teşkilatı arasındaki bağlantıyı sağlayan 2. Kolordu'nun Komutanı Selahattin Adil Bey, İbrahim Hannano, Şeyh Asım, Necip Uveyt gibi milli hareketimize taraftar olan Arap ileri gelenlerinden reislerinden bazılarını Maraş’a davet etmiş ve kendilerini Fransızlara karşı direnişe katılmaları konusunda ikna ederek bunların topraklarında Fransızlara karşı askeri faaliyetler yapmaya başlamalarını sağlamıştır. Suriye'nin kuzey coğrafyası Türkiye kaynaklı Kuvayı Milliye mensuplarının çok aktif olduğu topraklardır. Kuvayı Milliyeciler düşmana karşı işbirliği yapma konusunda Azez'in Arap asıllı kaymakamını ikna etmişlerdir ${ }^{10}$. Azez kaymakamı ile bizzat Mustafa Kemal Paşa'nın da zaman zaman dâhil olduğu görüşmelerde iki tarafın birbirlerini desteklemesi ve özellikle Suriye'de ve Güney Anadolu'da Fransız kuvvetlerinin askeri operasyonları ve askeri birlikleri takviye için kullandıkları ikmal - iaşe yollarının kesileceği saldırıların yapılması kararlaştırılmıştır (Çolakoğlu 1991: 133). Bu gibi ulaşım hatlarını tehdit edecek ve gerektiğinde etkili saldırılarla bu yolların kullanımını engelleyecek örgütlenmeler ile kısa sürede Hama, Lazkiye, Halep, İskenderun bölgesi ile bu güzergâhtaki yollar Fransızların kullanamayacakları kadar tehlikeli bir hale getirilmiştir (Üzel 1952: 228).

Birlikte hareket eden Türk ve Arap direniş̧̧ilerin etkili ve kararlı mücadeleleri sonucu güneye ve kuzeye doğru Hama - Lazkiye - Azez - Antep hattı boyunca Fransız ordusu zaman zaman adeta hareketsiz bırakılmıştır. Ayrıca Türk akıncı müfrezeleri de Halep - İskenderun yollarını kesmek amacıyla devamlı olarak akınlarda bulunmuşlardır. Bu ikili iş birliğinin sonucu, Fransızlar, hareket, nakliye ve ulaşım zorluğu nedeniyle garnizonlarına sıkışmış, böylece alan hakimiyeti direnişçilere geçmiştir. Nitekim İdlib ve Cebel-i Zaviye ${ }^{11}$ bölgelerinde Şam'dan bağımsız Arap Hükümetleri ilan edilerek, Fransızların buralardaki etkinliklerine son verilmiştir (Cebesoy 2017: 419).

Türk - Arap işbirliği yoğunlaştıkça ve çıkan sorunlar çözüldükçe Fransızlar gerek sınır kesimlerinde Türklerle olan mücadelelerinde gerekse Suriye'de Araplarla olan çatışmalarında oldukça sıkıntılı dönemler geçirmişler, ciddi güvenlik zaafiyetleri oluşmuştur. Öyleki, yerel milli güçlerin Fransızlara olan tepkisi doğrudan Başkomutan Gouraund'u hedef almaya kadar yönelmiş, General Gouraund, Halep’ten dönerken Hama ile Humus arasında Araplar tarafından pusuya düşürülmüştür. General Gouraund yaralı olarak kurtulmayı başarmıştır (ATASE, Kls. 1039, Dos. 215 - 124, Fih. 10).

Fransızlar, sıkıntıya düştükçe çareyi bölgeye mümkün olduğu kadar kuvvet yığmaya çalışmışlardır. Fransız kuvvetlerinin artan gücü hakkında Fevzi Paşa 14 Şubat 1921 tarihinde Mecliste yaptığı konuşmada şunları söylemiştir (TBMM Gizli Celse Zabıtları, 14 Şubat 1921, s. 425):

\footnotetext{
${ }^{10}$ Türk sınırına yakın Halep'in kuzeyinde bir şehir.

${ }^{11}$ Halep'in güneyinde bir Suriye kasabası (İdlib) ve bölgeye hâkim bir dağ (Cebel-i Zaviye).
} 
“Malumu Alileri Fransa'nın Kılikya'da ve Suriye'de bulundurduklar kuvvet, kendi ifadelerine göre 70 bine baliğ bulunuyor ve bunun için de General Guro (Gouraund) 100 milyon tahsisat almıştı. Bundan maada Ermenilerden istifade ediyor, Lübnanlllardan istifade ediyor. Asuri bakayasından istifade ediyor, jandarma teşkilatı yapıyor. Bizim buraya kuvvet tahsis etmekteki amacımız, Fransızların sahra muhaberesinde mağlup olmasın temin ve müteferrik kuvvetlerini mağlup etmek ve kendisini Suriye'de daima tehdit eltında bulundurmaktır. ..."

Fransızlar, Anadolu ve Suriye direnişi sırasında Avrupa'daki propaganda mekanizmalarını da güçlü bir silah olarak kullanmışlardır. Özellikle Fransız gazeteleri yaptıkları yayınlar ile Güney Anadolu ve Kuzey Suriye'de ki direnişi sıradan bir eşkıya hareketi olarak Avrupa kamuoylarına yaymaya çalışmışlardır. Bu propaganda zaman zaman etkili de olmuştur. Ancak hem Anadolu'daki hem Kuzey Suriye'deki direniş teşkilatlanması da bu hususta boş durmamıştır. Her iki bölgedeki gazeteciler, siyasiler ve eşraf Avrupa'nın büyük gazetelerine, konsolosluklara ve Milletler Cemiyeti'ne yaptıkları başvurularla ve çektikleri protesto telgrafları ile Fransız propagandasını yalanlayarak, ilgili bölgelerdeki direnişin, sömürgeciliğe ve emperyalizme karşı gerçekleştirilen bir halk direnişi olduğunu vurgulamışlardır (Umar 2003: 74).

\subsection{Suriye'nin Kuzeyini Anadolu'ya Bağlanma Çabaları}

Anadolu ve Suriye coğrafyalarında ortak düşmana karşı verilen mücadele başarıyla sürerken, Halep’te ve Kuzey Suriye'nin diğer kısımlarında yoğun olarak yaşayan Türklerin, doğal olarak Türkiye ile kaderlerini birleştirme çabaları olmuştur. 28 Şubat 1919'da Halep’te, İngiliz ve Araplara karşı Türklerin bazı gösteriler gerçekleştirmesi buna örnek olarak verilebilir. Bu tür eylemleri çoğu zaman sınıra yakın bölgelerde bulunan Kuvayı Milliye mensuplarınca organize ediyordu. Çünkü Suriye'deki bu etnik özellik Misakı Milli sınırlarına ulaşmak için önemli bir firsattı ve toparlanma olduktan sonra bu firsat kullanılmak isteniyordu.

Türkiye yanlısı niyetler ortaya koyan, ama TBMM ile bağlantısı olmayan, yerel Türk unsurlardan kaynaklanan bu gelişmeler bağımsızlık yanlısı Arapların bazı tereddütler içerisine düşmesine, Türk iş birliğine tam olarak güvenmemelerine neden olmuştur. Türk yetkililer, Arapların tereddütlerini gidermek, onların iş birliğini devam ettirmek için sürekli ve dikkatle çaba harcamışlardır. Antep Kuvayı Milliyesi’nin liderlerinden Polat Bey bu iş birliği için yoğun gayret gösterenlerdendir. 10 Nisan 1920 tarihinde Azez Kaymakamlığına gönderdiği yazıda Fransızların demiryolu ile askeri nakliyelerinin önlenmesi ve istihbarat raporlarının gönderilmesi hususundaki gecikmelerden yakınmış ve daha hassas davranılmasını talep etmiş̧ir. (Umar 2004: 436):

“Azez Kaymakamlığına,

Geçenlerde İslamlık adına yerine getirilmesi dileğinde bulunduğum konulara bir karşıllk verilmemiştir. Düşman Azez bölgesinde tam bir serbestlik içinde hareket etmekte ve saldırllarına devam etmektedir. Oysa Arap Hükümeti, Fransızların silah, cephane ve asker taşımalarını resmen 
yasaklamıştı. Bu yasağın uygulanmamasının nedenlerini milletime bildirmek zorundayım. Katma'daki kuvvetleriniz düşmanın en ufak hareketini bilecek konumdadır. Lütfen askerleriniz tarafindan verilecek rapor ve bilgileri bize iletiniz. Bu din, vatan ve memleket için gereklidir. Bunu ümit ederek saygllarımın kabulünü ve cevabınızı sabırsızlıkla bekleyeceğim."

Polat Bey'in 10 Nisan 1920 tarihli yazısına Araplar 12 Nisan 1920'de verdikleri cevapta, Arap bağımsızlığının tanınmadığını yönündeki endişelerini dile getirerek, bu konuda bir açıklama yapılmasını istemişlerdi. Bunun üzerine Polat Bey 19 Nisan 1920'de Halep Fırka Komutanlığı ile Erkânı Harbiye Riyasetine yazdığı yazıda bağımsız bir Suriye'yi gönülden istediklerini ve bunu gerçekleştirmenin tek yolunun da ortak düşmana karşı birlik içerisinde mücadele olduğunu ifade eder. Polat Bey'in yazısında aşağıdaki bölümler yer almaktadır (Umar 2004: 437):

"12 Nisan tarihli yazınızı saygı ile aldım. Mümkün olmayan isteklerde bulunduğumu sanmıyorum. Arap hükümetinin temel görüşünü ve Suriye'nin sinırlarını bilmekteyim. Bu sinırlar içerisinde kalan yerlerin Fransızlardan temizlenmesi elbette bizi de ilgilendirmektedir. Bu sinırlar içerisinde özgür bir Suriye'nin oluşmasın yürekten dilerim...

Polat Bey, her iki millet için ortaklaşmış amaçları da şöyle vurguluyor (Çolakoğlu 1991: 141 144):

“Türk milleti ateşkes koşullarının doğru dürüst uygulanmasını ahdetmiş bir Kuvayı Milliye oluşturmuştur. Amacımız önce dinimizi sonra da vatanımızı kurtarmaktır. Bu nedenle aynı amacı güden Arap savaşçıları ile birlikte hareket etmek yararımıza olacaktır. Saygılarımı içtenlikle sunar cevabınızı beklerim."

Türkler ve Araplar, din ve vatanlarını kurtaracaksa, bağımsız ve kendi coğrafyalarından egemen olacaklarsa, bu, ancak birlikte direnmekten geçecektir. Birlikte güvenlikleri her birinin güvenliği için gerekliydi. Sahada yaşanan gerçek böyle olmasaydı, her iki millet kendi topraklarında sömürgecilere karşı mücadele verirken, Türklerin ayrıca Suriye coğrafyasındaki mücadelede ne işleri olabilirdi?

\subsection{Suriye'nin Kuzeyinde Verilen Mücadelenin Siyasal Sonuçları}

Türkiye Büyük Millet Meclisi Hükümetleri tarafindan desteklenen ve yönlendirilen, sahada Selahattin Adil bey sorumluluğunda, Özdemir Bey tarafından organize edilen ve Halep'te bulunan Hilal bey tarafından yönetilen Suriye Kuvayı Milliye teşkilatının çalışmaları, Fransızları Suriye'de meşgul ederek, Suriye'den Anadolu'ya Fransız ordusunun naklini ve müdahalesini zorlaştırmış, güçlü Fransız ${ }^{12}$ ordusuna ağır kayıplar verdirerek, yıpranmasını sağlamıştır. Böylece Anadolu'da, Güney cephesinde Fransız Ordusuna karşı yürütülen mücadele önemli oranda etkili hale getirilmiştir.

\footnotetext{
${ }^{12}$ Alman ordusunu Avrupa'da durduran ve mağlup eden asıl güç Fransız ordusudur. İngiliz ordusu burada önemli katkı sağlasa da ikinci plandadır. Fransız ordusu bu dönemde yabana atılacak bir ordu değildir. Bu orduyu ana vatanından oldukça uzak bir bölgede iki cephede birden savaşa zorlamak ve bunu başarmak, Türkiye Büyük Millet Meclisi hükümeti açısından büyük bir taktiksel ve stratejik başarıdır.
} 
Türkiye Büyük Millet Meclisi, Arap halkların bağımsızlık mücadelelerini askeri ve siyasi olarak destekleyip, yönlendirirken, bu durumu İtilaf devletlerine açıkça göstermeye çalışmıştır. Komşu halklar arasında İtilaf Devletlerine ve onların mandacılık yöntemine karşı başlayan ve başarılı seyreden ciddi direniş bir bakıma TBMM' nin İtilaf devletlerine karşı kullandığı önemli bir koz da olmuştur. TBMM çeşitli propaganda vasıtaları ile bölgede varlığını sürekli göstermiş ve bu şekilde İngiliz ve Fransız siyasetçileri karşı uygun şartlarda bir barış anlaşması vücuda getirmek için etkin bir şekilde kullanmıştır (Açıkses 2010: 108 - 116).

Bu dönemde, sahadaki sıkıntılar, Fransa'yı istikrarsız bir politika gütmeye zorlamıştır. Bunda Fransa'nın müttefiki olan İtilaf Devletlerinin ve özellikle İngiltere'nin sık politika değişiklikleri, Fransa'ya verilmiş olan sözlerin unutulması, Yunanistan'ın İngilizlerce sürekli ön plana çıkarılmaya çalışılması gibi etkenler de rol oynamıştır. Bu şartlar altında Fransızlar, zaman zaman TBMM'ne karşı olumlu, anlaşmaya eğilimli politikalar izlemeye yönelmişlerdir. Ancak kısa dönemli dönüşümler dışında Fransızlar, TBMM' nin, Kuzey Suriye'de ve Güney Anadolu'da sert ve kanlı bir mücadele sergilediği düşmanı olmuştur (B1yıklı 2008: 330).

\section{Türkiye'nin Güneyinde Fransızlara Karşı Kazanılan Başarı ve Ankara}

\section{Antlaşması}

15 Eylül 1919’da imzalanan “Suriye İtilafnamesi”ne göre İngiltere Adana, Antep, Urfa, Maraş ve İskenderun'u Fransa'ya bırakıyor, Musul ise İngilizlerde kalıyordu (Atatürk'ün Tamim, Telgraf ve Beyannameleri 1991: 129). Bundan başka İngilizler Suriye bölgesinde Şam, Humus, Hama ve Halep’teki kuvvetlerini geri çekmiş, bunu müteakip de Fransa buraları işgal etmek için kuvvetlerini harekete geçirmiştir. Böylece daha önce İngiliz işgali altında bulunan yerler Fransa'ya bırakıldı. Bu mukaveleden her iki devlet memnun görünüyordu. Zira bölgede ekonomik çıkar elde etme yarış1 neticesinde Fransa Çukurova'nın pamuğunu, İngiltere de Musul'un petrolünü ele geçirdi. Kasım 1919'da İngiliz orduları komutanı Allenby Suriye'nin ve Kilikya'nın yönetimini Fransa yüksek komiseri General Goureaud'a devrederek bölgenin işgalcisinin ve tek söz sahibinin Fransızlar olduğunu ilan ediyordu. Mustafa Kemal Paşa, bu anlaşmadan haberdar olur olmaz, derhal acil olarak Erzurum Müdafaa-i Hukuk Merkeziyesi'ne çektiği telgrafla konuya dikkat çekmiş ve bu durumun idarecilere ve gazetelere duyurulması gerektiğini bildirmiştir (Olcay 1981: LXVI):

“15 Eylül 1919 günü Ingiltere ile Fransa, 1916 yılında imzaladıkları antlaşmayı esas alarak; "Suriye İtilafnamesi” adı altında milletimizi yakından ilgilendiren bir mukavele üzerinde anlaştılar. Bu mukavelenameye göre, İngilizlerin haksı olarak işgal ettikleri yerleri tahliye eyledikleri bölgeleri, Fransızlar haksızlı üzerine haksızlık yaparak işgale başlayacaklar, Halep'i hariçte bırakarak, Urfa, Ayıntap, Maraş ile Adana vilayetlerimizdeki çoğunluğu İslâm ve Türk olan ve zengin topraklarımızı işgal bölgelerine dâhil ederek, kuzeye doğru da Harput ve Sivas'a kadar uzanıp, buraları da dâhile 
alarak Mersin'in batısına kadar uzanan ve Batı Anadolu ile Doğu Anadolu'yu birbirinden ayıran bu bölgeler Fransiz nüfuz ve idaresine girecektir."

Bu bölge üzerinde Fransızların farklı planları da vardı. Tehcir kanunu ile bölgeden uzaklaştırılan Ermenileri Çukurova'ya yerleştirmek niyetindeydiler (Saip 1340: 43 - 49; ATASE, Kls. 6-2132, Dos. 383, Fih. 43). Fransızlar muhtemelen Ermenilere Çukurova'da bir devlet kurmayı vaat ederek (Sonyel 1972: 43 - 49), onları bölgede tutunacakları bir dal olarak kullanmak istiyorlardı. Bunun yanında Fransızlar bölgedeki güçlerinden tasarruf etmek zorunda kalırlarsa; ortaya çıkacak boşluğu dost ve müttefik bir Ermeni milisler ile kapatabileceklerini de düşünüyorlardı.

Daha önce ifade edildiği üzere, Fransız işgal birliklerine karşı Adana, Mersin, Tarsus, İslahiye ve Silifke'de oluşturulan Kuvayı Milliye birlikleri bölgede işgale karşı ciddi çalışmalar yaparlar. Maraş, Antep ve Urfa'da çok ciddi direniş gösterilir, ağır çatışmalar olur. Fransız birlikleri Urfa ve Maraş’tan geri çekilmek zorunda kalırlar. Bu bölgelerdeki Kuvayı Milliye'nin ordu birlikleriyle de desteklenmesi sonucu milli kuvvetlerin üstünlükleri ve hâkimiyetleri giderek artar. Suriye coğrafyasında da Fransa verilen mücadelelerle sıkıntı içine düşürülür. Fransızlar bölgede tutunamayacaklarını anlarlar. Olayların bu şekilde aleyhlerine gelişmesi üzerine Fransızlar Mayıs 1920'de Ankara Hükümeti ile ilişki kurmak için girişimlerde bulunurlar. Ankara'ya gelen bir Fransız heyeti ile 10 Mayıs 1920'de başlamak üzere yirmi günlük geçici nitelikte bir ateşkes anlaşması imzalanır (Toros 2001: 161). Görüşmeler sırasında Fransızlardan milli sınırlar içinde bulunan bölgelerin tümünün boşaltılması istenir. Ancak bu istek, Fransızlar tarafından reddedilir. Dolaysıyla ateşkes bir barış anlaşmasına dönüşemez.

Fransızların Anadolu'da karşılaştıkları direnç, Türk ve Suriye Kuvayı Milliyeleri karşısında uğradıkları başarısızlıklar, TBMM hükümetinin Ermenistan Cumhuriyetine karşı askeri başarısı ve iki taraf arasında imzalanan Gümrü Anlaşması, Sovyetler Birliği ile ilişkiler konusunda TBMM'nin attığı adımlar Fransız yöneticilerini Türk sorununu yavaş yavaş İngiltere'ye bağımlı olmaksızın değerlendirmeye yöneltmiştir. Nitekim daha önceleri Sevr Antlaşmasını değiştirmeye olanak bulunmadığını savunan Fransız Başbakanı Millerand ve onun yerine geçen Legues, artık bu anlaşma hükümlerinin değiştirilmesinden söz etmeye başlamışlardı.

Bu sıralarda Türk dostu olarak tanınan ünlü Fransız yazarı Pierre Loti de, Fransa'nın Türk siyasetini eleştiren yazılar yayınlamaya başlamıştı. 13 Aralık 1920 günü "Le Temps" gazetesinde çıkan “Doğu'da Barış Ne Zaman Kurulacak” başlıklı yazıda, Fransa'nın yalnız başına Türkler ile savaşmaya sürüklendiğine dikkat çekiyor ve soruyordu "Fransa'nın kanı ve parası acaba daha ne kadar Yunan kralı için sarf olunacak?” (Turan 1998 İkinci Kitap: 218 - 219). Batı Cephesi’nde elde edilen Birinci İnönü Zaferi'nden sonra konu edilen görüşmeler devam etmez, çünkü Ankara hükümeti Londra Konferansına davet edilir.

Türkiye Büyük Millet Meclisi Ordularının Yunan Ordusunu İnönü mevzilerinde ikinci kez durdurması, Ankara Hükümetinin pozisyonunu İtilaf Devletleri karşısında güçlendirmiştir. Bu dönemde 
Fevzi Paşa vekâleten Dışişleri Bakanlığı görevini yürütürken, Mayıs 1921'de TBMM Hükümeti, Dışişleri Bakanlığı görevlisi Münir Bey’i Fransızlarla teması sürdürmek üzere Adana'ya gönderir. Ancak Münir Bey’in götürdüğü teklifler Fransızlarca kabul edilebilir bulunmamıştır.

13 Haziran 1921'de Fransızların gayrı resmî temsilci olarak Ankara'ya gönderdikleri eski bakan Henry Franklin Bouillon ile TBMM - Fransa görüşmeleri tekrar başladı. Bekleneceği gibi Türk tarafi Misakı Millî'de 1srar ederken Fransız temsilci hem Sevr'in bir emri vaki olduğunu iddia ediyor hem de Bekir Sami Bey'in Londra'da imzaladığı anlaşmanın temel alınmasını istiyordu. Ancak Türk tarafının özellikle kapitülasyonlar ve tam bağımsızlık konularındaki kararlılığı görüşmelerin bir kez daha kesilmesine yol açtı (Budak 1987: 401 - 402).

Türkiye Büyük Millet Meclisi Ordularının 13 Eylül 1921 tarihi itibariyle Sakarya'nın doğusunda Yunan askeri gücü bırakmamış olması ve Yunanlıların Ankara'yı tehdit edecek saldırı güçlerinin kati surette imha edilmesi üzerine, Fransızlar Ankara hükümeti ile gayri resmi barış görüşmelerine tekrar başlama ihtiyacı hissettiler.

24 Eylül 1921'de Ankara'da Franklin Bouillion ile Ankara Hükümeti Dışişleri Bakanı Yusuf Kemal Bey başkanlığında bir heyet arasında ikinci aşama Türk - Fransız görüşmeleri başladı. Mustafa Kemal Paşa'da zaman zaman görüşmelere katılıyordu. Türk tarafı, sınırın Payas'tan başlayarak Çobanbey - Nusaybin arasındaki $20 \mathrm{~km}$. genişliğindeki Bağdat demiryolunun güneyinden geçtikten sonra Musul vilayetine kadar uzanmasında 1srar ederken, Boullion'da Fransız hükümetinden aldığı talimat doğrultusunda, her şeye rağmen, hiçbir taviz vermek niyetinde değildi.

Aslında hem Ankara hem de Fransızlar bir anlaşma ortaya çıkarmak istiyordu, ancak TBMM'nin Misakı Milli taleplerine Fransızların 1srarla karşı çıkmaları olası bir anlaşmayı zora sokuyordu. Bu noktada şu hususu dikkate almak lazımdır. Milli Mücadele hareketinin amacı, hareketin önderi Mustafa Kemal Paşa'nın da pek çok kez belirttiği gibi, kapitülasyonların kaldırılması, kayıtsız şartsız millet egemenliğinin ve tam bağımsızlığın sağlanması idi. Bu noktada Fransızların 1srar ettiği sınır hattının kabulü kolay değildi. Ancak Türkiye'nin o zaman içinde bulunduğu iç ve dış şartlar da daha iyisinin gerçekleştirilebilmesini de engelliyordu.

Ankara İtilafnamesi'nin TBMM'de kabulü de, bekleneceği üzere, hiç kolay olmamıştır. TBMM bu itilafnamenin hükümlerini uzun uzun tartışış, zaman zaman mebuslar arasında gerilimler olmuş, bazı mebuslar itilafname hükümlerine ağır eleştiriler getirmiştir. Ancak Mustafa Kemal Paşa'nın son derece sakin ve nazik bir üslupla yaptığı etkili ve ikna edici konuşmalar itilafnamenin onaylanmasını sağlamıştır.

20 Ekim 1921'de Yusuf Kemal Tengirşek ile Franklin Boullion tarafından TBMM Hükümeti ile Fransa arasında imzalanan "Ankara İtilafnamesi" ile Türkiye İtilaf Bloğunu bölmüş ve güçlü bir Avrupa devleti olan Fransa'nın desteğini elde etmiştir (Soysal 2000: 50 - 52; Olaylarla Türk Dış Politikası 1974: $42-43)$ : 
İtilafname, Türkiye ile Fransa arasında savaşın bittiğini belgeliyordu. Hatay-İskenderun dışındaki bugünkü güney sınırımız, yani günümüzdeki Suriye sınırı, Fransızlarca kabul ediliyordu. $\mathrm{Bu}$ sınırın kuzeyini Fransızlar boşaltacaklardı. Ankara Anlaşması ile İskenderun Sancağı Türkiye sınırları dışında kalıyordu, ancak anlaşmaya İskenderun'daki Türklerin çıkarlarını koruyacak ve bölgeye özerklik verilmesini sağlayacak hükümler konulmuştur (Uçarol 2000: 589).

İtilafname ile Birinci Dünya Savaş'ından beri savaştığımız düşmanlardan biri, TBMM'nin kurduğu devletin varlığını tanıyarak Kurtuluş Mücadelemizden çekilmiştir. Anlaşma Devletleri arasındaki birlik de böylece çözülmüştür. Güneyde Fransızlara karşı açılan cephe de kapandığı için o bölgede de güvenli bir ortam sağlanmıştır.

\section{Fransa Mandasında Suriye}

Osmanlı İmparatorluğundan koparılan Suriye, Irak ve Filistin'de manda idarelerinin kurulmasına dair nihai kararlar 19-26 Nisan 1920 tarihleri arasında gerçekleşen San Remo Konferansı'nda alınmıştır. Bu konferans, Ortadoğu'nun kaderini çizen paylaşım kararlarının uygulanması için dünya ölçeğinde ilk resmi adım olarak kabul edilebilir. Eski Osmanlı vilayetleri, Wilson Prensipleri ${ }^{13}$ gereği açikça sömürgeleştirilemiyordu (Wilson 1918: 287 - 294). Bu yüzden söz konusu coğrafya manda olarak adlandırılan bir paylaşım ve yönetim sistemi tasarlanarak, sömürgeci ülkelerin istek ve çıkarları doğrultusunda parçalandı ve belirli ilkeler çerçevesinde Milletler Cemiyeti'nin gözetiminde ilgili sömürgeci ülkelere verildi (Okur 2009: 140).

Konferansta alınan kararlara göre Suriye ve Lübnan Fransız mandasına bırakı1ırken, Irak, Filistin ve Ürdün ise İngiliz mandasına bırakıldı. Bu gelişme Şerif Hüseyin önderliğindeki isyanı anlamsız bırakıyor, dahası bu isyanı "ihanet” hükmünde olması noktasına getiriyordu (Karasapan 1942: 287; Küçük 1987: 39).

Suriye'nin Fransız mandası olarak kabul edilmesinin ardından Fransız orduları Beyrut'tan hareket ederek Şam'a doğru hızla ilerlemeye başladılar. Emir Faysal, elindeki askeri güç ile Fransız ilerleyişini ve başkent Şam'ın 25 Temmuz 1920'de Fransızların eline geçişini engelleyemedi (Umar 2004: 449). Faysal Avrupa'ya kaçmak zorunda kaldı ve İngilizler 1921'de onu Irak Kralı yapana kadar da Ortadoğu'ya geri dönemedi (Saray 2006: 78, Tuğ 1969: 279).

\footnotetext{
${ }^{13}$ ABD başkanı Woodrow Wilson ABD'nin barış koşullarını 8 Ocak 1918'de açıkladı. Bunlar bilinen 14 ilkedir. Wilson ilkelerinin tam metni için bkz. Wilson, Woodrow, «America's Terms of Peace, Message to Congress, January 8, 1918», World War Issues and Ideals, Boston, 1918, s. 287-294.
} 
Fransa, 1922 yılında Lübnan ve Suriye mandasını Milletler Cemiyeti’nden teslim aldı. Şam'ın işgalinden sonra Fransız Başbakanı Alexandre Millerand, Suriye'nin bundan sonra Fransa'nın elinde kalacağını “(Suriye’nin) tamamı ve sonsuza kadar” diyerek ilan etti (Fildiş 2013: 52 - 60).

İngiliz ve Fransızların ortak çalışmalarıyla Suriye, Filistin ve Lübnan mandaları 24 Temmuz 1922'de Milletler Cemiyeti Konseyinde resmen tanındı (Longrigg 1958: 374 - 380). Manda yasasının yürürlüğe girme tarihi 29 Eylül 1923 olup, bu tarih sonrasında Fransızlar Suriye’ye tamamen hâkim olmuşlardır.

Türkiye Büyük Millet Meclisi ile Fransa arasında savaşı sona erdiren bir itilafname yapılmasına rağmen TBMM Hükümeti, Suriye'de Fransızlara karşı mücadele eden Arap teşkilatlarına destek olmaya devam etmiştir. Milli Mücadele taraftarı olan Şammar Şeyhi Abdülkerim Bey'in, Mayıs 1922'de Hasiçe Nahiyesinde Fransızlara karşı verdiği mücadele Türkiye tarafından açık biçimde desteklenmiştir (ATASE, Kls. 215A - 214, Dos. 1626, Fih. 10). Bu tür eylemler Suriye'de Türkiye'ye karşı duyulan sempatinin ve bağlılığın devamını sağlamıştır. Halep Müdafaa-i Hukuk Cemiyeti Başkanı Hilal Bey tarafından 3 Haziran 1922 tarihinde verilen raporda Şam'da yapılan gösteride çoğunluğun "Yaşasın istiklal, yaşasın Mustafa Kemal ve O'nun himayesini istiyoruz" şeklinde nümayiş yaptıkları bildirilmektedir (ATASE, Kls. 215A - 214, Dos. No. 1626, Fih. 11-1).

Mustafa Kemal'in de bölgeye ilgisi devam etmiş, sonuçta 20 Ekim 1921 tarihli Ankara İtilafnamesi ile Fransızlara bırakılan Hatay uygun bir tertiple Türkiye topraklarına 29 Haziran 1939 tarihinde katılmıştır.

Fransa, Lübnan-Suriye coğrafyasına hâkim olduktan sonra bölgede, yukarıdaki analizlere uygun biçimde "böl ve yönet" şeklinde bir politika izledi. Gayrimüslim azınlıkları devlet yönetiminde ve ordu içerisinde güçlendirerek nüfusun çoğunluğunu oluşturan Sünnilere karşı azınlıkları destekledi. Fransızlar ayrıca Suriye'yi idari olarak da bölgelere ayırdılar. Öncelikle Lübnan Suriye'den ayrıldı ve Beyrut başkent olmak üzere himaye altında bir Lübnan devleti kuruldu. Lübnan'ın dışında kalan Suriye topraklarında ise Şam ve Halep merkezli iki devlet kuran Fransızlar, ayrıca birer Nusayri ve Dürzi devleti de kurdular. Böyle bir idari yapılanmayı gerçekleştiren Fransa, bölgede hâkimiyetini tam olarak kabul ettirdikten ve etnik konsolidasyonu sağladıktan sonra bu devletçikleri "Suriye Federasyonu" olarak tek devlet haline getirdi. 1925 yılında ise devletin ismi "Suriye Devleti" olarak belirlendi. Fransızların oluşturduğu siyasi ve idari yapı 1946 yılına, II. Dünya Savaşı sonuna kadar devam etti. 


\section{Sonuç}

Osmanlı Devleti egemenliği altındaki Arap coğrafyasında yüzyıllar boyunca, barış içinde yaşanmış, dış müdahaleler başlayana kadar etnik herhangi bir karışıklık ortaya çıkmamıştır. Suriye'yi manda olarak alan Fransa, Suriye coğrafyasını kolaylıkla yönetilebilir kılmak için farklı dini ve etnik grupları birbirinden keskin sınırlarla ayırma yoluna gitmiştir. Osmanlı Devleti'nin ve sonrasında Kuvayı Milliye hareketinin dayandığı, bölgede nüfusun çoğunluğunu oluşturan "Sünni Müslüman" kitle ise olabildiğince yönetimden uzaklaştırılmış, sosyal ve ekonomik olarak geri plana itilmiştir. Fransa'nın Suriye coğrafyasını sömürgeleştirirken ön plana çıkardığı ve desteklerini aldığı azınlık gruplar KatolikProtestan azınlıklardan Dürzi, Marunî ve Nusayri gibi heterodoks azınlıklara kadar geniş bir yelpazeye yayılıyordu. Suriye bölgesinde yoğun çabalarla oluşturulan bu etnik ve mezhepsel yapı, sömürgecilerin o toprakları kontrol altında tutmalarını sağlamıştır.

Milli Mücadele Hareketinin liderleri, Suriye politikalarını hem o coğrafyanın bağımsızlığı hem de Anadolu'daki mücadelenin başarısı üzerine kurmuşlardır. Misakı Milli'nin ilk maddesinde ifade edildiği gibi, Osmanlı Devletinden ayrılan Arap halklar kendi geleceklerini belirleme hakkına sahiptirler. Yani belli mücadele kadrosu bu halkların bağımsızlık taleplerine saygı göstermektedir. Düşmana Karşı mazlum halklar birlikte mücadele etmelidir, ancak zafere ulaşıldıktan sonra her ulus kendi kaderini tayin etme hakkına sahiptir. TBMM'nin bölgeye, Osmanlı Devleti bakiyesine karşı emperyalist amaçları olmamıştır. Başta Mustafa Kemal Paşa olmak üzere lider kadronun yaptıkları konuşmalara, verdikleri demeçlere baktığımızda, çevremizde yaşayan Arap-İslam toplulukları için samimi bir endişe içinde oldukları görülebilir.

Mustafa Kemal Paşa ve Milli Mücadelenin diğer liderleri Suriye ile ilgili politikalarını belirlerken, konuya sadece bir müslüman ve mazlum bir milletin ferdi olarak bakmak dışında taktik ve stratejik bazı hedefleri de göz önünde bulundurmuşlardır. Fransızlar, Birinci Dünya Savaşı'nın sonunda sadece Suriye'yi işgal etme çabası içinde değildirler. Güney Anadolu'nun önemli bir kısmı da Fransız işgali altına düşmüştür ve sömürgeleştirilme tehlikesi altındadır. Adana, Antep, Maraş ve Urfa İşgalci ordulara karşı yürütülen kanlı bir mücadelenin savaş alanı durumundadır. Bu durumda, Fransızlar hem Suriye'de hem Anadolu'da, koordineli sert bir mücadeleye zorlanarak, Anadolu'da Milli Mücadele'yi yürüten güçlerin karşısında zayıflatılmışlardır. Milli Mücadele'nin başlangıcından itibaren Suriye'de titizlikle güçlü bir Kuvayı Milliye teşkilatlanmasının oluşturulması ve Anadolu'daki mücadele ile koordineli bir mücadelenin hayata geçirilmesi yukarda sıraladığımız amaçlar nedeniyledir.

Kuvayı Milliye'nin ordu birlikleriyle desteklenmesi sonucu milli kuvvetlerin üstünlükleri ve hâkimiyetleri Anadolu'da giderek artarken, Suriye'de de Kuvayı Milliye hareketi Fransızları önemli ölçüde hareketsiz hale getirmiş, Anadolu'yu rahatlatmıştır. Olayların aleyhlerine gelişmesi üzerine Fransa Hükümeti Mayıs 1920'de Ankara Hükümeti ile ilişki kurmak için girişimlerde bulunur. Ankara’ya gelen bir Fransız heyeti ile 10 Mayıs 1920 'de başlamak üzere yirmi günlük geçici nitelikte 
bir ateşkes anlaşması imzalanır. TBMM Ordularının 13 Eylül 1921 tarihi itibariyle Sakarya'nın doğusunda Yunan askeri gücü bırakmamış olması ve Yunanlıların Ankara'yı tehdit edecek saldırı güçlerinin kati surette imha edilmesi üzerine, Fransızlar Ankara Hükümeti ile gayri resmi barış görüşmelerine tekrar başlama ihtiyacı hissettiler. 24 Eylül 1921'de Ankara'da Franklin Bouillion ile Ankara Hükümeti Dışişleri Bakanı Yusuf Kemal Bey başkanlığında bir heyet arasında ikinci aşama Türk - Fransız görüşmeleri başladı. Kapitülasyonların kaldırılması, kayıtsız şartsız millet egemenliğinin ve tam bağımsızlığın sağlanması Milli Mücadele Hareketi'nin esas hedefi idi. Bu noktada Fransızların 1srar ettiği sınır hattının kabulü kolay değildi. Ancak Türkiye'nin o zaman içinde bulunduğu iç ve dış şartlar da daha iyisinin gerçekleştirilebilmesini de engelliyordu.

Ankara İtilafnamesi’nin TBMM'de kabulü de, bekleneceği üzere, hiç kolay olmamıştır. TBMM bu İtilafnamenin hükümlerini uzun uzun tartışmış, zaman zaman mebuslar arasında gerilimler olmuş, bazı mebuslar İtilafname hükümlerine ağır eleştiriler getirmiştir. Ancak konu ile tartışmaların bulunduğu TBMM Gizli Celse Zabıtları incelendiğinde Mustafa Kemal Paşa, son derece sakin ve nazik bir üslupla yaptığı etkili ve ikna edici konuşmalar ile İtilafnamenin onaylanmasını sağlamıştır.

20 Ekim 1921'de TBMM Hükümeti Dış İşleri Vekili Yusuf Kemal Tengirşek ile Franklin Boullion tarafından TBMM Hükümeti ile Fransa arasında "Ankara İtilafnamesi" imzalanmıştır. Bu İtilafname ile Türkiye, Fransa ile savaşı bitirmiş, İtilaf Bloğunu bölmüş ve güçlü bir Avrupa devleti olan Fransa'nın desteğini elde etmiştir. Güneyde Fransızlara karşı açılan cephe de kapandığı için o bölgede de güvenli bir ortam sağlanmıştır. Suriye ise, o coğrafyada verilen ciddi mücadeleye karşın, sömürgecilerin dış politik ilişkileri ile 1925 yılından itibaren Birleşmiş Milletler kararıyla Fransa mandasına verilmiştir.

Bugün Suriye'de yaşananların temelindeki en büyük etmen, Fransızların 1925-1945 arasında o coğrafyada oluşturdukları etnik konsolidasyon ve azınlığa -mezhepsel etnik ayırıma dayanan demografik yapıdır. Sömürgecinin yirmi yılda kurduğu sistem, on yıllarca etkisini istendiği gibi sürdürebilmekte ve yeri geldiğinde yine sömürgeciler lehine uygun müdahalelere imkân verebilmektedir. Bu noktada, gelişmelerden ciddi şekilde ve hatta gelecek güvensizliği boyutunda etkilenen Türkiye ve bölge ülkeleri, Suriye coğrafyasında yaşananları, Suriye ve bölge tarihini iyi bilmek ve doğru analizler yapmak durumundadır. Bölünmenin ve emperyalistlere güvenerek onların adına çalışmanın nelere mal olduğunun ve mal olabileceğinin test edilerek görülebileceği en iyi sosyal laboratuvarlardan birisi Suriye'dir. 


\section{Kaynakça}

ATASE, Kls. 6-2132, Dos. 383, Fih. 43.

ATASE, Kls. 215A - 214, Dos. 1626, Fih. 10.

ATASE, Kls. 215A - 214, Dos. 1626, Fih. 11-1.

ATASE, Kls. 584, Dos. 8 - 141, Fih. 5-1.

ATASE, Kls. 584, Dos. 8 - 141, Fih. 5-2.

ATASE, Kls. 599, Dos. 29-154, Fih. 1.

ATASE, Kls. 599, Dos. 29-154, Fih. 1-3.

ATASE, Kls. 599, Dos. 29-154, Fih. 21.

ATASE, Kls. 599, Dos. 29 -154, Fih. 35.

ATASE, Kls. 809, Dos. 62, Fih. 62-6.

ATASE, Kls. 1039, Dos. 215 - 124, Fih. 10.

ATASE, Kls. 1690, Dos. 240 - 463, Fih. 1-3.

Akbıyı, Yaşar (1990) Milli Mücadele'de Güney Cephesi (Maraş), Türk Tarih Kurumu, Ankara.

Akşin, Apdülahat (1991) Atatürk’ün Dış Politika İlkeleri ve Diplomasisi, Türk Tarih Kurumu, Ankara.

Akşin, Sina (1986) “Turkish-Syrian Relations in the Time of Faisal (1918-20)”, Turkish Yearbook of International Relations, Ankara, ss. 3-17.

Akyüz, Yahya (1988) Türk Kurtuluş Savaşı ve Fransız Kamuoyu, Türk Tarih Kurumu Yayınları, Ankara.

Kolektif (2005) Atatürk’ün Tamim, Telgraf ve Beyannameleri, Cilt IV, Ankara, Türk İnkılap Tarihi Enstitüsü Yayınları, TTK Basımevi.

Atatürk, Mustafa Kemal (2001) Atatürk’ün Bütün Eserleri, Cilt 6, Kaynak Yayınları, İstanbul.

Bıyıklı, Mustafa (2008) “Kemal Atatürk ve Türkiye Cumhuriyeti’nin Ortadoğu’ya Yönelik Siyasi, Askeri Yaklaşımları ve Politikaları”, Mustafa Bıyıklı (Ed), Türk Dış Politikası-Cumhuriyet Dönemi-, Cilt 2, Gökkubbe Yayınları, İstanbul.

Bilgenoğlu, Ali (2006) II. Meşrutiyet Dönemi Arap Milliyetçi Cemiyetleri Ve Faaliyetleri, Dokuz Eylül Üniversitesi Sosyal Bilimler Enstitüsü, Yayınlanmamış Yüksek Lisans Tezi, İzmir.

Birsel, Haktan (2012) “Orta Doğu ve Türkiye Jeopolitiğine Etkileri Üzerine Bir Değer Olarak Suriye ve Suriye Demografisi”, Ed. Barış Adıbelli, Emperyalizm Oyununda İkinci Perde Arap Baharı ve Suriye, IQ Yayınları, İstanbul.

Budak, Mustafa (Temmuz 1987) “Ankara İtilafnâmesi Sürecinde Suriye Sınırı Üzerindeki Tartışmalar”, Atatürk Araştırma Merkezi Dergisi, Cilt: XIII, Say1: 38, ss. 397-425.

Çolakoğlu, Şinasi (1991) Kilis Direnişi, Kurtuluş ve Sonrası, 1918, 1921 - 1930, Onur Yayınları, Ankara.

Cebesoy, Ali Fuat (2017) Milli Mücadele Hatıraları, Temel Yayınları.

Davulcu, Mehmet (2007) Faysal Döneminde Türkiye-Suriye Ilişskileri (1918-1920), Ankara Üniversitesi Türk İnkılap Tarihi Enstitüsü, Yayınlanmamış Yüksek Lisans Tezi, Ankara.

Demir, Şerif (2011) “Dünden Bugüne Türkiye'nin Suriye ve Ortadoğu Politikası”, Turkish Studies -International Periodical For The Languages, Terature and History of Turkish or Turkic, Volume 6/3, ss. 691 - 713.

Evans, Laurence (1972) Türkiye’nin Paylaşılması (1914 - 1924), (Çev. Tevfik Alanay), Milliyet Yayınları, İstanbul.

Fildiş, Ayşe Tekdal (Nisan 2013) “Günümüzde Suriye'de Yaşanan Sorunların Tarihsel Arka Planına Kısa Bir Bakış”, Ortadoğu Analiz, Cilt: 5, Sayı: 52, ss. 55-62.

Fromkin, David (1993) Barışa Son Veren Barış, (Çev: Mehmet Harmancı), Sabah Yayınları, İstanbul.

Güner, Zekai (2007) “Antep Savunması Ve Ali Şefik Özdemir Bey’in Faaliyetleri”, ZKÜ Sosyal Bilimler Dergisi, Cilt 3, Say1 6, ss. 49-65. 
Gürel, Şükrü Sina (1984) Kıbrıs Tarihi 2 (1878 - 1960), Kaynak Yayınları, İstanbul.

Güztoklusu, Murat (2010) Özdemir Bey'in Filistin - Suriye Kuvayl Milliyesi ve El Cezire Konfederasyonu, Platin Yayınları, İstanbul.

Haas, Ernest Bernard (1952) "The Reconciliation of Conflicting Colonial Policy Aims: Acceptance of the League of Nations Mandate System” Haas, International Organization, 6(4), ss. 521-536.

Hâkimiyeti Milliye, 6 Şubat 1921.

Hâkimiyeti Milliye, 11 Şubat 1921.

İğdemir, Uluğ (1989) Heyeti Temsiliye Tutanaklarl, Türk Tarih Kurumu, Ankara.

Jackson, Peter (2013) Beyond the Balance of Power: France and the Politics of National Security in the Era of the First World War, Cambridge University Press.

Karasapan, Celal Tevfik (1942) Filistin ve Şark'ül Ürdün, Cilt 1, Ahmet İhsan Basımevi, İstanbul.

Kasalak, Kadir (2006) “Suriye'de Manda Yönetiminin Kurulması ve Türkiye'ye Etkisi”, Orta Doğu Araştırmaları Dergisi, Cilt 4, Sayı 2, T.C. Frrat Üniversitesi Orta Doğu Araştırmaları Merkezi, Elazığ ss. 69-87.

Khoury, Philips (1983) Notables, Nationalists and Faysal's Arab Government in Damascus, 1918-20. In Urban Notables and Arab Nationalism: The Politics of Damascus 1860-1920, Cambridge. Cambridge University Press.

Kocabaş, Süleyman (1993) Osmanlı İsyanlarında Yabancı Parmă̆̆ (1595 - 1913), Vatan Yayınları, İstanbul.

Küçük, Cevdet (1987) “Lübnan Meselesi”, Türk Dünyası Tarih Dergisi, İstanbul, ss. 35-40.

Longrigg, Stephen (1958) Syria and Lebanon Under French Mandate, Londra: Oxford University Press.

Okur, Mehmet Akif (2009) "Emperyalizmin Ortadoğu Tecrübesinden Bir Kesit: Suriye'de Fransız Mandası", Bilig, Kış Sayısı, Sayı 48, ss. 137-156.

Olcay, Osman (1981) Sevr Antlaşması'na Doğru (Çeşitli Konferans ve Toplantı Tutanakları ve Bunlara İlişskin Belgeler), Ankara Üniversitesi Siyasal Bilgiler Fakültesi Yayınları No. 455, Ankara.

Özçelik, İsmail (1992) Milli Mücadelede Güney Cephesi (Urfa), Kültür Bakanlı̆̆ı Yayınları, Ankara.

Saip (Ursavaş), Ali (1924) Kilikya Faciaları ve Urfa'nın Kurtuluş Mücadeleleri, Matbaa-i Ahmet İhsan ve Şürekâsı, Ankara.

Sar, Cem ve Arkadaşları (1974) Olaylarla Türk Dış Politikası, Ankara Ünv. Siyasal Bilgiler Fakültesi Yayınları, Ankara.

Saray, Mehmet (2006) Türkiye ve Yakın Komşuları, Atatürk Araştırma Merkezi Yayınları, Ankara.

Selek, Sabahattin (2002) Milli Mücadele, Cilt 1, Örgün Yayınları, İstanbul.

Sonyel, Salahi Ramadan (1987) Türk Kurtuluşs savaşı ve Dış Politika, Cilt: 1, Türk Tarih Kurumu, Ankara.

Sonyel, Salahi Ramadan (1972) "Yeni Belgelerin Işı̆̆ı Altında Ermeni Mezalimi”. Belleten, C. XXXVI. Sayı 141, Ocak, Ankara, ss. 31-49.

Soysal, İsmail (1987) İki Dünya Savaşı Arasında Türk Arap İlişkileri (1919 - 1939), Foundation for Studies on Turkish - Arab Relations, Cilt: 2-3, İstanbul.

Soysal, İsmail (2000) Türkiye'nin Siyasal Antlaşmaları (1920 - 1945), Cilt I, Türk Tarih Kurumu Basımevi, Ankara.

Şahin, Mustafa ve Şahin, Cemile (2014) "Türk İstiklal Harbi’nde Askerlik Şubeleri Ve Kilis Askerlik Şubesi", Atatürk Üniversitesi Türkiyat Araşttrmaları Enstitüsü Dergisi, Sayı 52, Erzurum, ss. 273-294.

Şimşir, Bilal (2006) Atatürk Dönemi İncelemeleri, Atatürk Araştırma Merkezi, Ankara.

Şimşir, Bilal (1973) İngiliz Belgelerinde Atatürk (1919-1938), Türk Tarih Kurumu Basımevi, Ankara.

Tanenbaumi, Jan Karl (1978) "France and the Arab Middle East, 1914-1920". Transactions of the American Philosophical Society, Vol. 68, No. 7.

TBMM Gizli Celse Zabıtları, Cilt: 1, Devre: 1, İçtima: 1, 2. İn'ikat, 4. Celse, 24 Nisan 1920.

TBMM Gizli Celse Zabıtları, Cilt: 1, Devre: 1, İçtima: 1, 13. İn'ikat, 2. Ve 3. Celseler, 9 Mayıs 1920.

TBMM Gizli Celse Zabıtları, Cilt: 1, Devre: 1, İçtima: 1, 150. İn'ikat, 3. Celse, 14 Şubat 1921. 
Tekin, Mehmet (1993) Hatay Tarihi, Hatay Kültür Ve Turizm Vakfı, Antakya.

Toros, Taha (2001) Kurtuluş Savaşı’nda Çukurova, Kültür Bakanlığı Yayınları, Ankara.

Tuğ, Salih ve Balcı, Muharrem (1969) Íslam Ülkelerinde Anayasa Hareketleri, İrfan Yayınevi, İstanbul.

Turan, Şerafettin (1998) Türk Devrim Tarihi, 2. Kitap, İstanbul.

Tüzün, Süleyman (1989) İki Büyük Savaş Arası Dönemde Hatay Tarihi (1918-1939), Hacettepe Üniversitesi, Atatürk İlkeleri ve İnkılap Tarihi Enstitüsü Yayınlanmamış Yüksek Lisans Tezi, Ankara.

Uçar, Nail (1989) “Şerif Hüseyin'in Oğulları, Hıyanet ve Nedamet”, Türk Dünyası Tarih Dergisi, Sayı: 28, ss. 59-61.

Uçarol, Rıfat (2000) Siyasi Tarih (1789 - 1999), Filiz Kitapevi, İstanbul.

Umar, Ömer Osman (2004) Osmanlı Yönetimi ve Fransız Manda İdaresi Altında Suriye 1908 - 1938, Atatürk Araştırma Merkezi Yayınları, Ankara.

Umar, Ömer Osman (1999) "Suriye'de Kurulan Kuvayı Milliye Teşkilatı ve Üyeleri”, Türk Dünyası Araştırmaları Dergisi, Sayı: 121, Elazı̆̆ ss. 87-96.

Umar, Ömer Osman (2003) Türkiye - Suriye İlişkileri (1918 - 1940), Fırat Üniversitesi Ortadoğu Araştırmaları Merkezi Yayınları, Sayı: 102, Elazı̆̆.

Üzel, Sahir (1952) Gaziantep Savaşının İç Yüzü, Doğuş Matbaası, Ankara.

Wilson, Woodrow (1918) America's Terms of Peace Message to Congress, January 8, World War Issues and Ideals, Boston.

Yılmaz, Hadiye (2014) "Mustafa Kemal Paşa - Emir Faysal Anlaşması ve Milli Mücadele Döneminde Suriye ve Irak” Cumhuriyet Tarihi Araştırmaları Dergisi, Y11: 10, Sayı: 20, ss. 289-306.

Yılmaz, Yahya (2017) “Mondros’tan Ankara Anlaşması'na İskenderun-Antakya Bölgesinin Durumu, İşgallere Karşı Mustafa Kemal Paşa'nın Tepkisi ve Tayfur (Sökmen) Bey’in Faaliyetleri (1918-1921)”, Gaziantep University Journal of Social Sciences, Cilt 17, Sayı 1, ss. 378-403.

Yorulmaz, Şerife (2005) “Çukurova'da Kuvayı Milliye Yapılanmasının Temel Özellikleri”. Ankara Ünv. Türk İnk. Tar. Ens, Atatürk Yolu Dergisi, Cilt: 9, Say1: 35, ss. 345-373.

Zamir, Meir (1991) "Faisal And The Lebanese Question, 1918-20", Middle Eastern Studies, Volume 27, Issue 3. Volume 27, Issue 3, ss. $401-426$. 